\title{
THE
}

2000

\section{A Case Study of Ship Track Formation in a Polluted Marine Boundary Layer}

\author{
Kevin J. Noone \\ Doug W. Johnson \\ Jonathan P. Taylor \\ Ronald J. Ferek \\ Tim Garrett
}

See next page for additional authors

Follow this and additional works at: https://digitalcommons.uri.edu/gsofacpubs

\section{Citation/Publisher Attribution}

Noone, K. J., Johnson, D. W., Taylor, J. P., Ferek, R. J., Garrett, T., Hobbs, P. V., Durkee, P. A.,...Pockalny, R. A. (2000). A Case Study of Ship Track Formation in a Polluted Marine Boundary Layer. J. Atmos. Sci., 57, 2748-2764. doi: 10.1175/1520-0469(2000)0572.0.CO;2 Available at: https://doi.org/10.1175/1520-0469(2000)057<2729:ACSOSF>2.0.C0;2

This Article is brought to you for free and open access by the Graduate School of Oceanography at DigitalCommons@URI. It has been accepted for inclusion in Graduate School of Oceanography Faculty Publications by an authorized administrator of DigitalCommons@URI. For more information, please contact digitalcommons-group@uri.edu. 


\section{Authors}

Kevin J. Noone, Doug W. Johnson, Jonathan P. Taylor, Ronald J. Ferek, Tim Garrett, Peter V. Hobbs, Philip A. Durkee, Kurt Nielsen, Elisabeth Öström, Colin O'Dowd, Michael H. Smith, Lynn M. Russell, Richard C. Flagan, John H. Seinfeld, Lieve De Bock, René E. Van Grieken, James G. Hudson, lan Brooks, Richard F. Gasparovic, and Robert Pockalny 


\title{
A Case Study of Ship Track Formation in a Polluted Marine Boundary Layer
}

\author{
Kevin J. Noone, ${ }^{a}$ Doug W. Johnson, ${ }^{\mathrm{b}}$ Jonathan P. Taylor, ${ }^{\mathrm{b}}$ Ronald J. Ferek,,${ }^{c, m}$ Tim Garrett, ${ }^{\mathrm{c}}$ \\ Peter V. Hobbs,,${ }^{c}$ Philip A. Durkee, ${ }^{d}$ Kurt Nielsen, ${ }^{d}$ Elisabeth Öström, ${ }^{a}$ Colin O’Dowd, ${ }^{e}$ \\ Michael H. Smith, ${ }^{\mathrm{e}}$ Lynn M. Russell, ${ }^{\mathrm{f}}$ Richard C. Flagan, ${ }^{\mathrm{g}}$ John H. Seinfeld,

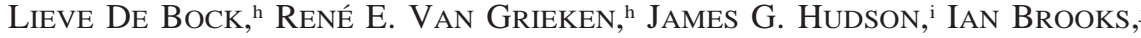 \\ Richard F. Gasparovic, ${ }^{k}$ AND Robert A. POCKALNY ${ }^{1}$ \\ a Department of Meteorology, Stockholm University, Stockholm, Sweden \\ ${ }^{\mathrm{b}}$ Meteorological Research Flight, The Met. Office, Farnborough, Hampshire, United Kingdom \\ ${ }^{c}$ Department of Atmospheric Sciences, University of Washington, Seattle, Washington \\ ${ }^{d}$ Department of Meteorology, Naval Postgraduate School, Monterey, California \\ ${ }^{\mathrm{e}}$ Centre for Marine and Atmospheric Sciences, University of Sunderland, Sunderland, United Kingdom \\ ${ }^{\mathrm{f}}$ Department of Chemical Engineering, Princeton University, Princeton, New Jersey \\ ${ }^{\mathrm{g}}$ Chemical Engineering, California Institute of Technology, Pasadena, California \\ ${ }^{\mathrm{h}}$ Department of Chemistry, University of Antwerp, Wilrijk-Antwerp, Belgium \\ i Desert Research Institute, University of Nevada, Reno, Nevada \\ j Scripps Institution of Oceanography, University of California, San Diego, La Jolla, California \\ ${ }^{k}$ Applied Physics Laboratory, The Johns Hopkins University, Laurel, Maryland \\ ${ }^{1}$ Graduate School of Oceanography, University of Rhode Island, Narragansett, Rhode Island
}

(Manuscript received 30 July 1996, in final form 6 August 1997)

\begin{abstract}
A case study of the effects of ship emissions on the microphysical, radiative, and chemical properties of polluted marine boundary layer clouds is presented. Two ship tracks are discussed in detail. In situ measurements of cloud drop size distributions, liquid water content, and cloud radiative properties, as well as aerosol size distributions (outside-cloud, interstitial, and cloud droplet residual particles) and aerosol chemistry, are presented. These are related to remotely sensed measurements of cloud radiative properties.

The authors examine the processes behind ship track formation in a polluted marine boundary layer as an example of the effects of anthropogenic particulate pollution on the albedo of marine stratiform clouds.
\end{abstract}

\section{Introduction}

\section{a. Anthropogenic effects on cloud albedo}

It has long been recognized that anthropogenically produced particulate matter can have an effect on cloud albedo. Dramatic examples of such effects have been seen in satellite imagery ever since the early TIROS satellites became operational three decades ago (Conover 1966). A hypothesis presented for the cause of the "anomalous cloud lines" observed in the early TIROS imagery was that particles produced by ships under "rather special atmospheric conditions" acted as cloud condensation nuclei (CCN) and led to the formation of lines of enhanced albedo in the clouds. The special at-

${ }^{m}$ Current affiliation: Office of Naval Research, Washington, D.C.

Corresponding author address: Dr. Kevin J. Noone, Department of Meteorology, Stockholm University, S-106 91 Stockholm, Sweden. E-mail: zippy@misu.su.se mospheric conditions included 1) a convectively unstable layer from the surface to a low-level stable layer, 2) saturation or slight supersaturation near the top of the convective layer, and 3) a convective layer presumably deficient in cloud forming nuclei (Conover 1966). Twomey et al. (1968) remarked that the observations presented by Conover (1966) were consistent with the addition of CCN to a cloud layer with drop concentrations of about $1-10 \mathrm{~cm}^{-3}$ - a very clean marine boundary layer. The anomalous cloud lines have been observed regularly in satellite imagery since Conover's original work and have become known as ship tracks in subsequent literature.

A number of investigations of the ship track phenomenon, both theoretical and experimental, have been done in the intervening years. Twomey (1974) presented a link between cloud reflectance, droplet size, and CCN concentrations, which is at the heart of the ship track phenomenon. In a later paper, Twomey (1991) used ship tracks as an example to illustrate the point that marine stratiform clouds, due to their typically low droplet number concentrations, may be particularly sensitive to 
the addition of $\mathrm{CCN}$, which can lead to the formation of additional droplets and subsequently increase the reflectivity (albedo) of the clouds. This effect was clearly demonstrated by Coakley et al. (1987), who presented radiance measurements from the advanced very high resolution radiometer (AVHRR) instruments on board National Oceanic and Atmospheric Administration (NOAA) polar-orbiting satellites at several wavelengths that showed considerable variability in the radiative properties of the background clouds, but still clear differences (especially in 3.7- $\mu \mathrm{m}$ radiance) between ship tracks and the surrounding clouds. Platnick and Twomey (1994) further expanded upon the concept of the relationship between changes in droplet number concentrations and cloud albedo (cloud susceptibility) using radiative transfer calculations and AVHRR measurements. They presented observations of ship tracks in a number of locations and showed that the "susceptibility" (the increase in cloud albedo for a unit increase in drop concentration) of the clouds in which the tracks formed was between $0.23 \times 10^{-3}$ and $20 \times 10^{-3} \mathrm{~cm}^{3}$. The wide range of susceptbility values indicates the extent to which variations in background $\mathrm{CCN}$ and cloud droplet concentrations affect how clouds react to increasing aerosol loadings. Taylor and McHaffie (1994) investigated the relationship between stratocumulus cloud susceptibility and aerosol concentration. They found that clouds forming in air masses in which aerosol concentrations were in excess of $500 \mathrm{~cm}^{-3}$ had low susceptibilities-typically $0.5 \times 10^{-3} \mathrm{~cm}^{3}$ - close to the lowest values observed by Platnick and Twomey (1994). Clouds forming in less polluted air masses had higher susceptibilities.

The first detailed coupling between in situ measurements of the microphysical and radiative properties of clouds and remote sensing measurements of ship tracks was presented by Radke et al. (1989). They showed clear increases in aerosol and droplet number concentrations in ship tracks, as well as a shift toward smaller droplet size and increased upwelling radiative fluxes in the ship tracks compared with the surrounding clouds. They also observed an increase in liquid water content (LWC) in the ship tracks (LWC is assumed to be constant in many derivations of cloud susceptibility) and speculated that the increase may have been due to a suppression of drizzle in the ship tracks. King et al. (1993) also found similar microphysical changes in ship tracks off the coast of southern California. They observed an increase of upwelling intensity at $0.744 \mu \mathrm{m}$ from $40 \mathrm{~W} \mathrm{~m}^{-2}$ in ambient clouds to $110 \mathrm{~W} \mathrm{~m}^{-2}$ in a ship track. The total optical thickness increased from 20 in the ambient clouds to 67 in the ship track and was attributed to a decrease in the size of the cloud droplets in the ship track. Additionally, they observed that the bulk of the increase in optical thickness in the ship tracks occurred in the lower portion of the cloud, which was consistent with a subcloud CCN source.

\section{b. Ship track formation in a polluted boundary layer}

A common observation among many of these studies is that the albedo of polluted clouds is less likely to measurably increase as a result of an addition of CCN as compared with the case for clean clouds. Nevertheless, the ubiquitousness of ship tracks in satellite imagery (at least in some coastal locations) suggests that they can form even in polluted boundary layers.

During the month of June 1994, ship tracks were encountered in boundary layers that were clean as well as moderately polluted (Noone et al. 2000). In this paper we shall present an investigation of ship track formation in a polluted marine boundary layer on 11 June 1994.

\section{c. Questions to be addressed}

The Monterey Area Ship Track (MAST) experiment was designed to test a set of 10 specific hypotheses regarding the causes of ship track formation and how the tracks are maintained for long periods in a convective boundary layer (Durkee et al. 2000b). Tests of the various hypotheses are presented in other papers (e.g., Durkee et al. 2000c; Ferek et al. 2000; Durkee et al. 2000a).

The analysis we present here is a case study of one of the days during the campaign in which the marine boundary layer in the operations area was polluted. We will address several questions in this paper:

- What kind of cloud microphysical changes occur in ship tracks that form in polluted marine stratiform clouds?

- What is the microphysical and chemical nature of the aerosol upon which the ambient clouds and ship tracks form in a polluted marine boundary layer?

- Can we identify or exclude any ship-produced particle sources related to cloud droplet formation in ship tracks?

- Are the radiative properties of the ship tracks similar at different wavelengths?

- Do the radiative properties of the ship tracks derived from in situ measurements differ from those derived from remotely sensed measurements?

\section{Experimental description}

\section{a. MAST approach}

The MAST experiment took place in June 1994 off the coast of central California. The base of operations was at the Naval Postgraduate School in Monterey, California. The experimental approach involved coordinated missions involving several different platforms aimed at testing a specific subset of 10 hypotheses regarding the formation and life cycle of ship tracks. A general overview of the experiment, the hypotheses, and the details of each of the platforms (including specific instrumentation on each platform) are given elsewhere (Durkee et al. 2000b). 


\section{b. Platforms and instrumentation}

A number of different platforms were involved in the MAST experiment: three aircraft [the University of Washington C-131A, Meteorological Research Flight C-130, and the National Aeronautics and Space Administration (NASA) ER-2], an airship (Naval Research Laboratory blimp), a research vessel (the R/V Glorita), and NOAA and Defense Meteorological Satellite Program satellites. In addition, various U.S. Navy vessels were available during certain periods of the experiment for special maneuvers. Ships of opportunity were investigated when navy vessels were not available.

\section{1) UNIVERSITY OF WASHINGTON (UW) CONVAIR C-131A}

A primary aim of investigators on the UW C-131A was to examine the chemical and microphysical nature of aerosols and clouds and aerosol-cloud interactions. The instrumentation on the C-131A has been described in detail elsewhere (Hobbs et al. 1991). In addition to the C-131A's normal payload, several guest investigators were on board the aircraft during MAST. CCN measurements were made using a continuous-flow CCN spectrometer (Hudson 1989). Aerosol size distributions between 0.003 - and $0.1-\mu \mathrm{m}$ radius were measured using a Radially Classified Aerosol Detector (RCAD; Russell et al. 1996). The chemical and microphysical properties of cloud droplet residual aerosol particles were measured using a counterflow virtual impactor (CVI; Noone et al. 1988; Ogren et al. 1985).

\section{2) MRF C-130 W MK. 2 Hercules (C-130)}

The Meteorological Research Flight (MRF), a part of the U.K. Meteorological Office, operates a Royal Air Force C-130 Hercules aircraft that has been modified extensively to make it suited to a wide range of atmospheric research work. A complete description of the standard meteorological instrumentation is given in Rogers et al. (1995), of the cloud physics instrumentation in Brown (1993) and Martin et al. (1994). The thermal volatility and size distributions of aerosol particles were also measured on board the C-130 using a volatile aerosol composition and concentration system (VACC; O’Dowd and Smith 1993).

A major aim of the C-130 investigators was to investigate the thermodynamic nature of the marine boundary layer, the microphysical and radiative properties of clouds, and the microphysics and chemistry of aerosol particles.

\section{3) NASA ER-2}

The NASA ER-2 high-altitude aircraft made a total of seven flights during the MAST campaign; 11 June was its first flight of the campaign. It has a nominal cruising altitude of $20 \mathrm{~km}$ and included instruments that provided high spatial resolution images of ship tracks and the surrounding stratocumulus clouds. In this paper we shall discuss data taken using the Moderate Resolution Imaging Spectroradiometer (MODIS) Airborne Simulator (MAS), which is a modified Daedalus multispectral scanner. The MAS records images at 11 wavelengths between 0.657 and $11.930 \mu \mathrm{m}$.

\section{4) R/V GLORITA}

The Research Vessel Glorita provided soundings of thermodynamic parameters during the experiment (Syrett 1994). In addition, instruments on board included a condensation nuclei counter, cloud radar system, sidescanning lidar, and a ceilometer, which were operated by investigators from several groups.

\section{5) SHips INVESTIGATED}

Two of the three ships investigated on this day will be discussed here. The Brazilian Vitoria is a 74139 ton ore/oil carrier. She is driven by a $21500-\mathrm{kW}$ diesel engine that nominally consumes $1 \mathrm{~kg} \mathrm{~s}^{-1}$ of fuel (we were not able to obtain the specific fuel type). She has a cruising speed of 7-8 $\mathrm{m} \mathrm{s}^{-1}$, a length of $273 \mathrm{~m}$, beam of $44 \mathrm{~m}$, and a draft of $16 \mathrm{~m}$.

The Kurama is a 57870 -ton container ship. She is powered by a $41200-\mathrm{kW}$ diesel engine that consumes roughly $2 \mathrm{~kg} \mathrm{~s}^{-1}$ of IFO 380 diesel fuel. She cruises at $12 \mathrm{~m} \mathrm{~s}^{-1}$ and has a length of $290 \mathrm{~m}$, a beam of $32 \mathrm{~m}$, and a draft of $12 \mathrm{~m}$. The two ships were steaming nearly parallel to each other but in opposite directions during the time of the investigations. The Brazilian Vitoria was heading in a southeasterly direction, while the Kurama was steaming toward the northwest. A more complete description of the ships is given in Hobbs et al. (2000).

\section{Background marine boundary layer characteristics}

\section{a. Thermodynamics and imagery}

Figure 1 shows vertical profiles of temperature and dewpoint temperature from balloon soundings taken from the R/V Glorita, and a profile through the boundary layer taken from the MRF C-130. Figure 1a shows radiosonde soundings from the Glorita at 3 times during the day. After having deepened during the day at the Glorita location, the inversion height stabilized at 450 $\mathrm{m}$ at about 1100 local time (1800 UTC). A C-130 profile (centered at near $35.5^{\circ} \mathrm{N}, 125.5^{\circ} \mathrm{W}-\mathrm{SSW}$ of the Glorita location; Figs. 1b,c,d) showed an inversion height of $480 \mathrm{~m}$, with a stratocumulus cloud deck between 260 and $480 \mathrm{~m}$. Cloud base was fairly indistinct, and it was very hazy in the boundary layer below cloud.

Cloud-top height was at circa $480 \mathrm{~m}$ at this point, at 

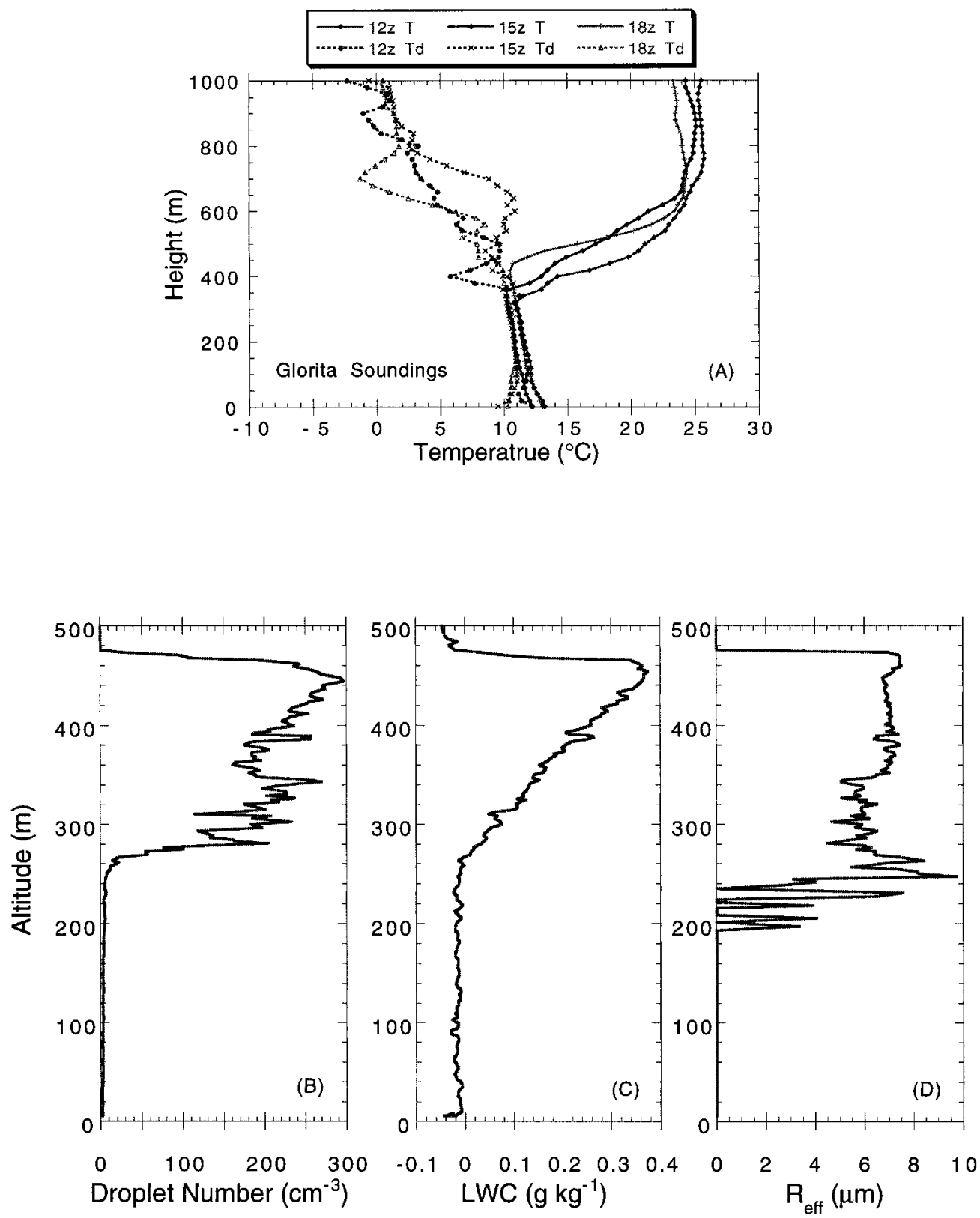

FIG. 1. (a) Vertical profiles of temperature and dewpoint temperature taken from the R/V Glorita on 11 Jun 1994 at 1100, 1400, and 1700 local time (1800, 2100, and 0000 UTC); (b)-(d) profile through cloud from the MRF C-130 centered at $35.5^{\circ} \mathrm{N}, 125.5^{\circ} \mathrm{W}$. Droplet number from Particle Measuring Systems FSSP-100 (b), liquid water content from Johnson-Williams LWH (c), effective radius derived from FSSP.

the same level as a strong $\left(10^{\circ} \mathrm{C}\right)$ temperature inversion. Cloud base varied between typically 250 and $300 \mathrm{~m}$ and was relatively indistinct. It was quite hazy below the cloud deck. Droplet number concentrations were between 200 and $300 \mathrm{~cm}^{-3}$, increasing slightly with height in the cloud. Liquid water content increased nearly linearly with height within the cloud deck, reaching a maximum of close to $0.4 \mathrm{~g} \mathrm{~kg}^{-1}$ at cloud top. Droplet effective radius at this location [measured from Forward Scattering Spectrometer Probe (FSSP) distributions] was between 6 and $8 \mu \mathrm{m}$, increasing slightly with height in the cloud. Effective radius values where the droplet number concentration was below $5 \mathrm{~cm}^{-3}$ have been excluded.

Profiles of total water and equivalent potential temperature showed the boundary layer to have been well mixed throughout the entire subcloud layer. Both parameters increased in cloud, suggesting buoyant sorting of air parcels. The sea surface temperature at the bottom of the MRF C-130 profile varied between 286.7 and 287.1 K. The air temperature at the surface (calculated 


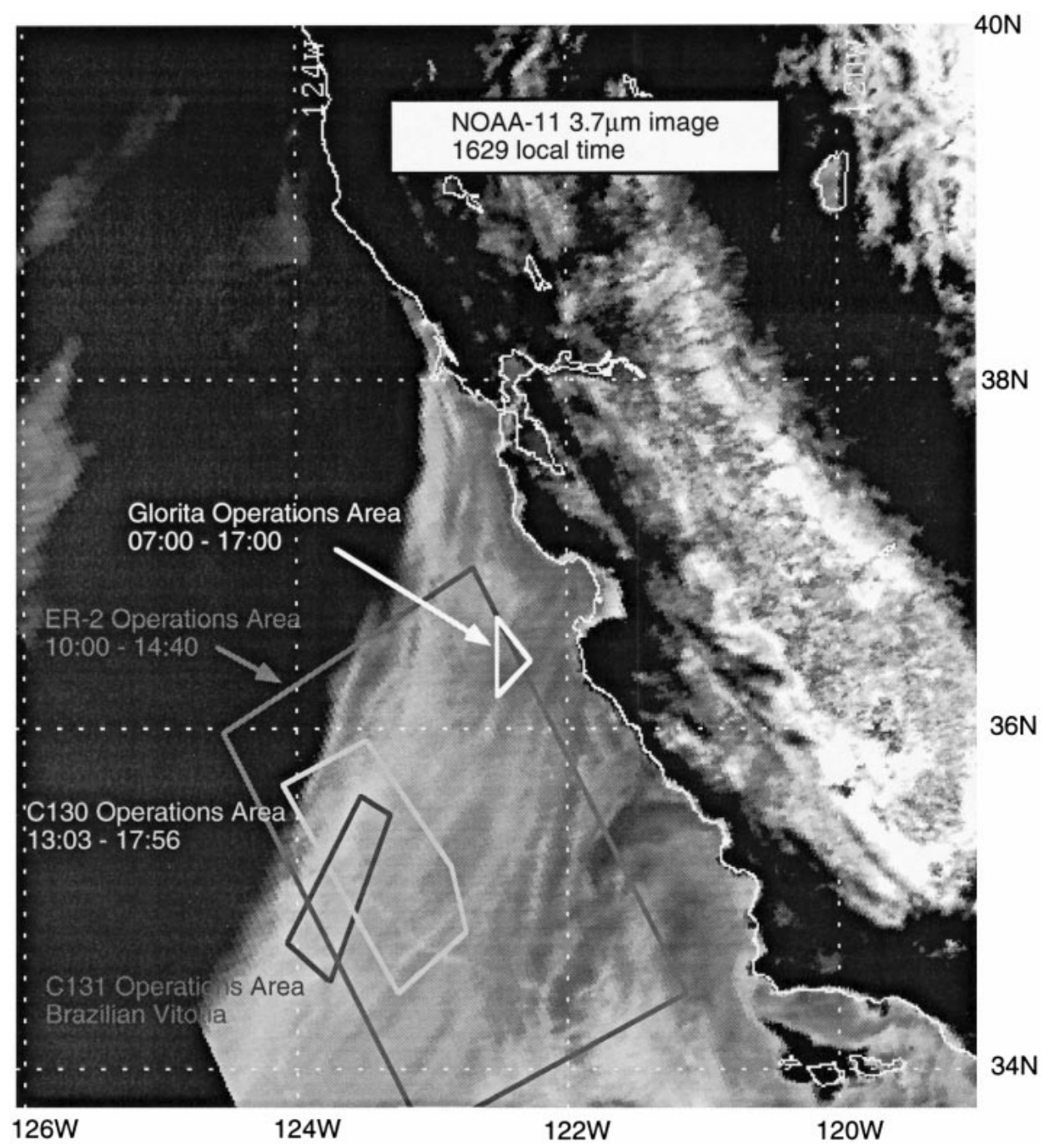

FIG. 2. NOAA-11 AVHRR satellite image at 3.7- $\mu \mathrm{m}$ wavelength at 1629 local time showing the operations areas for the various platforms. The Brazilian Vitoria and Kurama ship tracks are apparent as a " $X$ " in the lower part of the image.

by extrapolating the measured lapse rate during the profile to the surface) was $287.4 \mathrm{~K}$.

The sensible heat and buoyancy fluxes in the boundary layer were positive, but small at or less than $2 \mathrm{~W}$ $\mathrm{m}^{-2}$. The latent heat flux was calculated to be approximately $8 \mathrm{~W} \mathrm{~m}^{-2}$ at $150-\mathrm{m}$ altitude, and near zero in cloud. The Reynolds stress was relatively low on this day- $0.02 \mathrm{~Pa}$ at the $150-\mathrm{m}$ level. Although no legs were flown by the MRF C-130 at very low level, the low fluxes at $150 \mathrm{~m}$ and the fact that the surface air temperature was slightly above the sea surface temperature imply that the surface buoyancy forcing should have been effectively zero.

Figure 2 is an image from the NOAA-11 satellite showing the operations area for 11 June. The image was taken at 1629 local time and is in the 3.7- $\mu \mathrm{m}$ channel of the AVHRR instrument on the satellite. Monterey Bay in central California is in the center of the image at near $37^{\circ} \mathrm{N}, 122^{\circ} \mathrm{W}$. The operations areas of the various platforms are shown on the image. The aircraft were operating roughly at $34^{\circ}-36^{\circ} \mathrm{N}, 122^{\circ}-124^{\circ} \mathrm{W}$. On this day, the R/V Glorita was operating NE of the aircraft, closer to the Californian coast.

Two tracks can be seen to cross in the image, just above the southeast edge of the C-130A operations area. The Brazilian Vitoria track is the one running SW-NE in the image in Fig. 2. The Brazilian Vitoria track had advected southeast between the time that the aircraft were on station and the time that the image was taken. Its location corresponds well with Gaussian plume dispersion-advection calculations using a moving point source in a constant wind field (Petersen and Lavdas 1986). Using this puff dispersion model, we can estimate the location of the plume at any given time or, alternatively, the age of the track at any given aircraft encounter. 


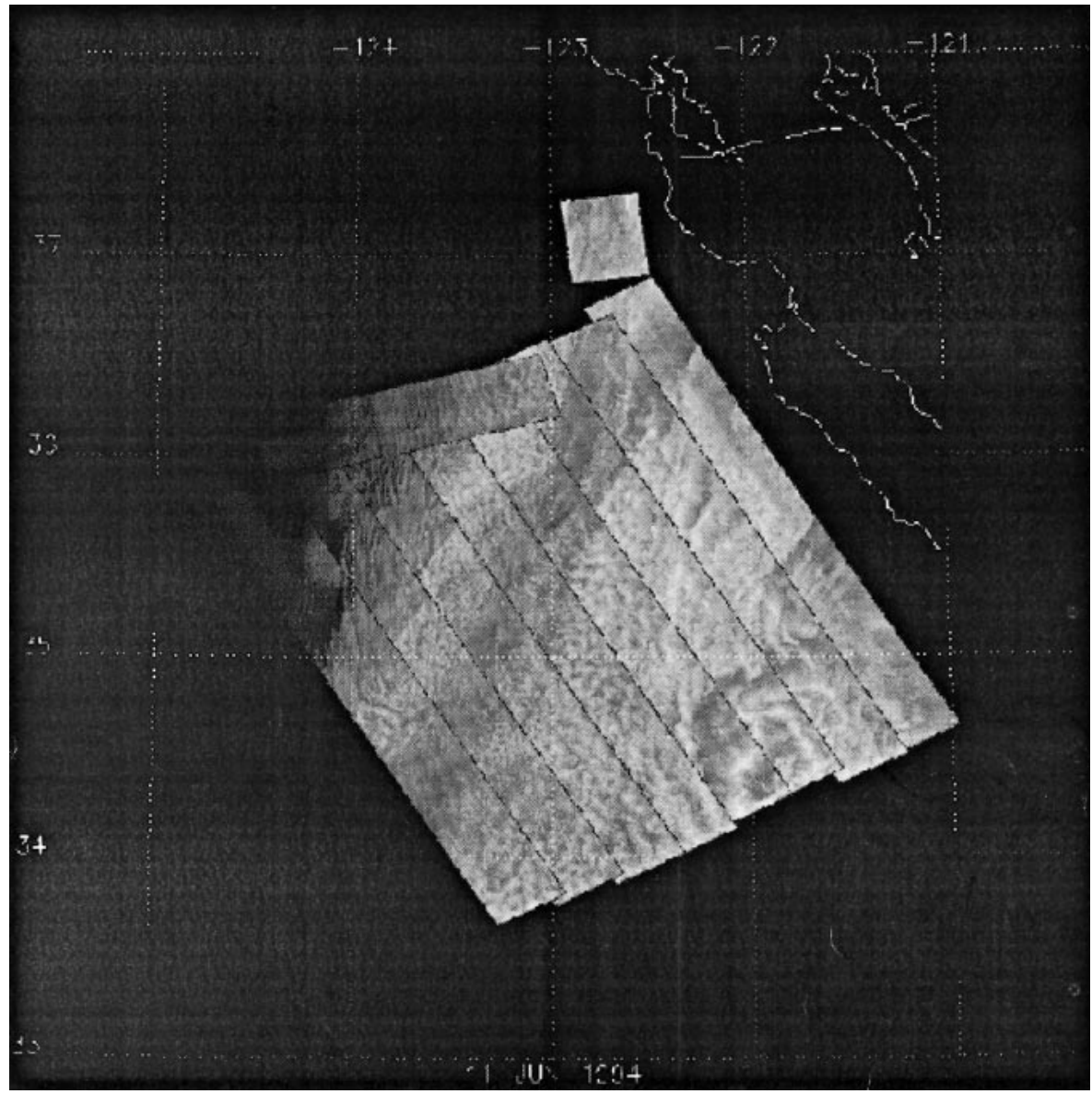

FIG. 3. Composite of visible $(0.66 \mu \mathrm{m})$ MAS imagery from the NASA ER-2.

Figure 3 is a composite of a series of images taken with the MAS instrument on board the NASA ER-2 aircraft. The images are $0.66-\mu \mathrm{m}$ (visible) radiances observed along each leg of the ER-2's flight track. The legs were approximately $22-23 \mathrm{~min}$ in duration. The leg closest to the coast was flown first, starting at about 1030 local time. Discontinuities are apparent in cloud properties between each leg. These discontinuities are due to changes with time in the cloud deck between ER-2 passes over adjacent areas.

The MAS composite visible image shows considerably more detail in terms of cloud structure than the AVHRR imagery. Despite the increased resolution, neither of the ship tracks apparent in the AVHRR 3.7- $\mu \mathrm{m}$ image can be seen in Fig. 3. High-resolution photographs were also taken from the ER-2 along the flight track, and no evidence of the ship tracks can be found in these images. The MAS also has a 3.7- $\mu \mathrm{m}$ channel. Tracks were not observed in these images. However, the MAS 3.7- $\mu \mathrm{m}$ images were difficult to interpret on this day due to bright lines in five of the 10 flight lines that were due to the particular orientation of the sun, clouds, and the aircraft.

Whatever phenomena that caused the tracks to be apparent in the 3.7- $\mu \mathrm{m}$ AVHRR image did not cause a similar effect in the visible range of the spectrum. We shall return to this point in more detail after discussing cloud and aerosol microphysical details in the ship tracks.

\section{b. Aerosol properties}

The thermal volatility of the $0.05-1-\mu \mathrm{m}$ radius (accumulation mode) aerosol was characterized aboard the MRF C-130, giving an indication of its chemical composition. The aerosol was sampled through an inlet on the aircraft via a heating system to an optical particle counter [Particle Measuring Systems (PMS) ASASP-X] where the particles were counted and sized. This technique has been used in a number of investigations (e.g., O'Dowd and Smith 1993; Clarke et al. 1987) and was operated by investigators from the University of Manchester Institute of Science and Technology (UMIST), Manchester, United Kingdom.

A typical run with this system (VACC) was to first sample the ambient aerosol and heat it to three temperatures $\left(40^{\circ}, 150^{\circ}\right.$, and $\left.340^{\circ} \mathrm{C}\right)$ in separate steps. Sulfuric acid volatilizes at approximately $100^{\circ} \mathrm{C}$, so changes in the 
aerosol size distribution between $40^{\circ}$ and $150^{\circ} \mathrm{C}$ are interpreted as being due to loss of $\mathrm{H}_{2} \mathrm{SO}_{4}$. Ammonium sulfate/bisulfate volatilizes between $150^{\circ}$ and $340^{\circ} \mathrm{C}$, and changes in the size distributions between these temperatures are interpreted as being due to the loss of these compounds. The aerosol remaining at $340^{\circ} \mathrm{C}$ is assumed to be either sea salt or elemental carbon.

There is a limitation to this technique when compounds other than sulfuric acid, partially or totally neutralized sulfate, sea salt, or soot are present in the aerosol. Organic compounds were found to have been present in the aerosol (Russell et al. 2000; Noone et al. 2000). The analyzed polycyclic aromatic hydrocarbon components were found in concentrations typically between 1 and $100 \mathrm{ng} \mathrm{m}^{-3}$. These compounds typically have boiling points at or above $340^{\circ} \mathrm{C}$ and could therefore be interpreted as sea salt or elemental carbon. There may also have been other lighter molecular weight organic compounds in the aerosol that volatilize at lower temperatures, thus potentially confounding the interpretation of the sulfuric acid and sulfate components. No other information is available as to the presence or absence of such compounds in the aerosol, and the following discussion will assume that they do not contribute substantially to the thermal characteristics of the aerosol.

Figure 4 shows size distributions from the volatility system taken in the vicinity of the Brazilian Vitoria at three different altitudes and three different temperatures: $40^{\circ}, 150^{\circ}$, and $340^{\circ} \mathrm{C}$. Figure $4 \mathrm{c}$ shows size distributions from the marine boundary layer below cloud. At $40^{\circ} \mathrm{C}$ the particle concentration was roughly $200 \mathrm{~cm}^{-3}$, and the mode size was about $0.11-\mu \mathrm{m}$ radius. There was a $17 \%$ loss of particle number after heating to $150^{\circ} \mathrm{C}$ (a corresponding decrease of $39 \%$ in aerosol volume), and the mode size decreased to about $0.09 \mu \mathrm{m}$. Apparently some material (sulfuric acid or organic material) was volatilized from the ambient aerosol upon heating to $150^{\circ} \mathrm{C}$, but the fact that there was only a slight decrease in particle number indicates that the aerosol was partially internally and externally mixed. The particle concentration after heating to $340^{\circ} \mathrm{C}$ was only $22 \mathrm{~cm}^{-3}$, which were likely to have been sea salt particles. Thermal volatility analysis indicates that in the boundary layer, by number most of the particles were ammonium sulfate or bisulfate, and about $10 \%$ were sea salt. The sea salt component dominated the number in the size range above about $0.2-\mu \mathrm{m}$ radius, while the sulfate particles were found primarily in the sub-0.2- $\mu \mathrm{m}$ range.

Interstitial aerosol distributions at the same three temperatures are shown in Fig. 4b. The interstitial aerosol concentrations are lower than below cloud $-79 \%$ of the number of accumulation-mode particles measured by the VACC system at $40^{\circ} \mathrm{C}$ were taken up into cloud droplets. There was a $48 \%$ decrease in interstitial particle number upon heating to $150^{\circ} \mathrm{C}$, but in this case there was no apparent change in the size distribution. A decrease in number with no change in size is interpreted as an external mixture of aerosol particles. Only
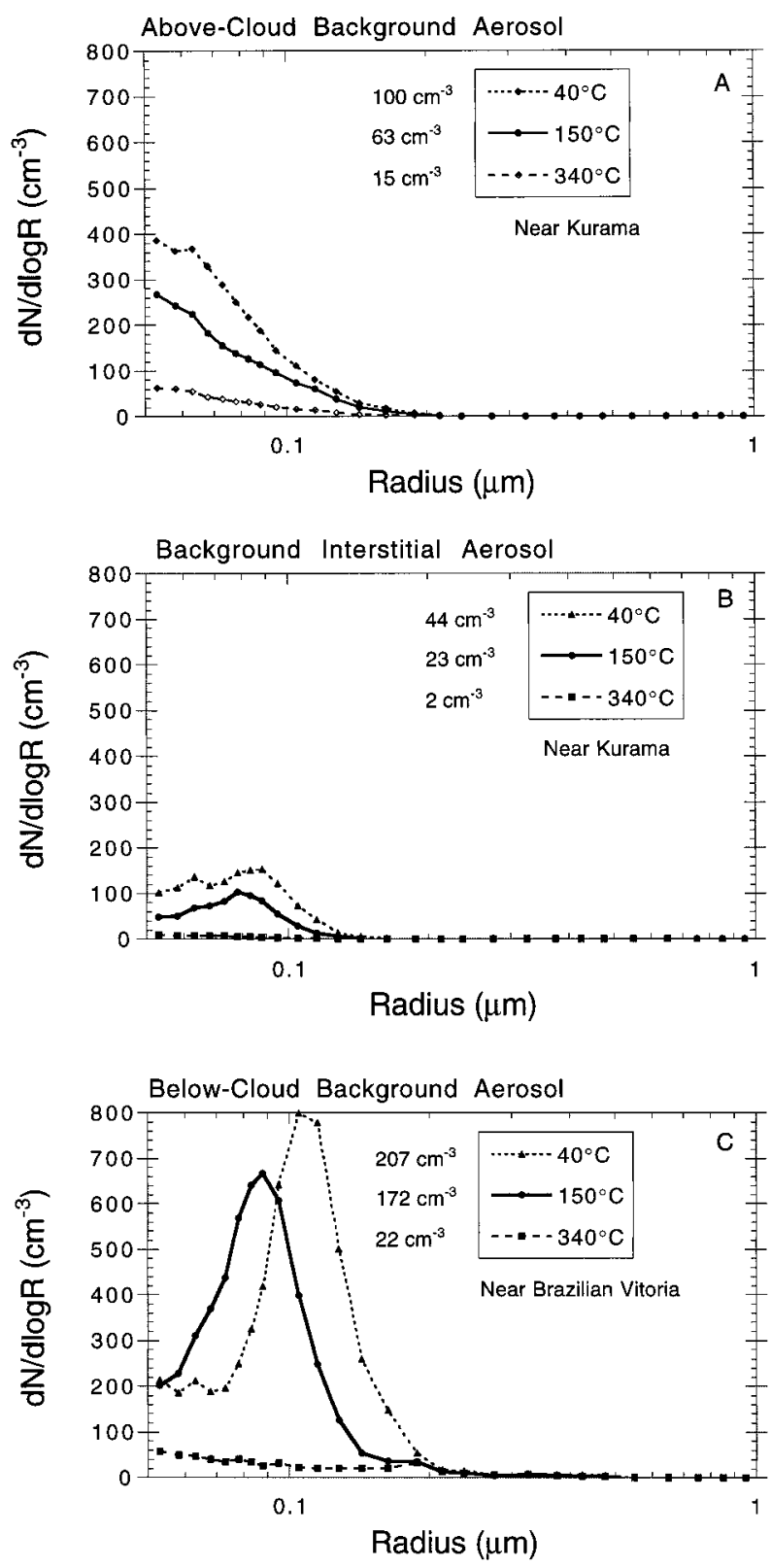

FIG. 4. Aerosol size distributions (measured with the UMIST VACC system on the MRF C-130) at three temperatures $\left(40^{\circ}, 150^{\circ}\right.$, and $340^{\circ} \mathrm{C}$ ) for (a) above-cloud aerosol, (b) background interstitial aerosol, and (c) background below-cloud aerosol.

$2-\mathrm{cm}^{-3}$ sea salt particles were left in the interstitial air, indicating that about $90 \%$ of the salt particles were taken up into the cloud droplets.

The above-cloud background aerosol size distributions are shown in Fig. 4a. The distributions have very different shapes compared with the boundary layer aerosol, and the concentrations were a factor of 2 lower. On this day, the marine boundary layer accumulation-mode aerosol concentration was twice the above-cloud concentration: 200 $\mathrm{cm}^{-3}$ below cloud and $100 \mathrm{~cm}^{-3}$ above cloud. 
TABLE 1. Summary of transect averages. Average values were calculated for equal intervals in and on either side of a ship track. The units are the following: droplet number $\left(N_{d}\right)$, total aerosol $\left[N_{a}(\mathrm{~T})\right]$, and accumulation-mode aerosol $\left[N_{a}(\mathrm{P})\right]-\mathrm{cm}^{-3}$; liquid water content $[\mathrm{LWC}(\mathrm{p})]-\mathrm{g} \mathrm{m}^{-3}$; droplet effective radius $\left(r_{e}\right)-\mu \mathrm{m}$. Ratios are taken as the track value divided by the average of the two ambient cloud values on either side of the track. Effective radii were calculated from the average droplet size distributions.

\begin{tabular}{|c|c|c|c|c|c|c|c|c|c|c|c|}
\hline \multirow[b]{2}{*}{ Transect } & \multirow[b]{2}{*}{ Parameter } & \multicolumn{3}{|c|}{ Before track } & \multicolumn{3}{|c|}{ Track } & \multicolumn{3}{|c|}{ After track } & \multirow[b]{2}{*}{ Ratio } \\
\hline & & Mean & Std dev & Count & Mean & Std dev & Count & Mean & Std dev & Count & \\
\hline \multirow[t]{5}{*}{6} & $N_{d}$ & 211 & 24.2 & 40 & 226 & 21.3 & 40 & 208 & 23 & 40 & 1.08 \\
\hline & LWC (p) & 0.321 & 0.038 & 40 & 0.31 & 0.027 & 40 & 0.358 & 0.058 & 40 & 0.91 \\
\hline & $N_{a}(\mathrm{~T})$ & 652 & 60.6 & 40 & 1194 & 168.4 & 40 & 471 & 16.4 & 40 & 2.13 \\
\hline & $N_{a}(\mathrm{P})$ & 158 & 30.8 & 40 & 241 & 65.8 & 40 & 135 & 30.6 & 40 & 1.65 \\
\hline & $r_{e}$ & 9.0 & - & - & 8.9 & - & - & 9.3 & - & - & 0.97 \\
\hline \multirow[t]{5}{*}{11} & $N_{d}$ & 220 & 26.1 & 116 & 222 & 27.4 & 116 & 216 & 26.3 & 116 & 1.02 \\
\hline & LWC (p) & 0.344 & 0.053 & 116 & 0.288 & 0.036 & 116 & 0.27 & 0.042 & 116 & 0.94 \\
\hline & $N_{a}(\mathrm{~T})$ & 467 & 28.5 & 116 & 713 & 88.4 & 116 & 577 & 35.8 & 116 & 1.37 \\
\hline & $N_{a}(\mathrm{P})$ & 131 & 37 & 116 & 177 & 48.3 & 116 & 141 & 38.1 & 116 & 1.30 \\
\hline & $r_{e}$ & 8.8 & - & - & 8.5 & - & - & 8.3 & - & - & 0.99 \\
\hline
\end{tabular}

\section{Ship track characteristics}

\section{a. Brazilian Vitoria}

Twelve passes through the Brazilian Vitoria ship track were made by the UW C-131A between 1200 and 1430 local time. Since the differences between subsequent track encounters were small, only two will be discussed in detail: one approximately $8.5 \mathrm{~km}$ from the ship (transect 6), and the other roughly $16 \mathrm{~km}$ away (transect 11). The wind in the boundary layer was from $340^{\circ}-350^{\circ}$ at $6-8 \mathrm{~m} \mathrm{~s}^{-1}$, and the ship was steaming close to the wind, so that the plume age at any given encounter is greater than the distance from the ship divided by the mean wind speed. Transect 6 was at $35.13^{\circ} \mathrm{N}, 123.64^{\circ} \mathrm{W}$; the track age here was approximately $3 \mathrm{~h}$ old. Transect 11 was at $34.62^{\circ} \mathrm{N}, 123.85^{\circ} \mathrm{W}$, at which point the track was approximately $6 \mathrm{~h}$ old.

A summary of selected parameters for the two transects is presented in Table 1. Average values, standard deviations, and the number of observations are given for before-track, track, and after-track periods. The final column in the table gives the ratio of the in-track value and the average of the before- and after-track values.

\section{1) TRAnSECT 6}

Transect 6 is a track encounter approximately $8.5 \mathrm{~km}$ from the ship when the track was about $3 \mathrm{~h}$ old. Time series for this transect are shown in Fig. 5. The track at this point was $3.4 \mathrm{~km}$ wide. Distinct particle plumes are apparent in both accumulation-mode (Fig. 5c) and total particle number concentrations (Fig. 5d). Droplet number was $8 \%$ higher in the track with respect to the bordering clouds, but this increase was not statistically significant ( $p=0.99$ ). Liquid water content increased after the ship track, leading to a larger LWC value for the after-track average. Effective radius was essentially constant at $10 \mu \mathrm{m}$ for this run. Once again, no statistically significant changes in droplet number (Fig. 5b) or liquid water content (Fig. 5a) were observed above the background variability. Droplet effective radii were no different in the track $(8.5 \mu \mathrm{m})$ than before and after the track (9.0 and $9.3 \mu \mathrm{m}$ respectively.)

Drop size distributions for transect 6 are shown in Fig. 6a. As in transects closer to the ship, no differences were observed between the track and the ambient clouds. There was a considerable difference in residual particle size distributions in this transect, as can be seen in Fig. 6b. The in-track average distribution was clearly shifted toward larger particles; there were fewer residual particles below $0.08 \mu \mathrm{m}$ and more particles between 0.1 and $0.2 \mu \mathrm{m}$.

While drop size distributions did not change substantially across the track, the number mean size of the cloud droplet residual particles increased by $7 \%$ inside the track. Few additional droplets were formed in the ship track in this case; however, the droplets present in the track released larger aerosol particles upon evaporation than their neighbors in the surrounding clouds. One explanation for this feature is that the increased concentration of particles in the track (particularly in the accumulation-mode range) increased the competition for the condensable water vapor being made available by the upward motion of air in the cloud. As a result, the peak supersaturation in the track could have been less than in the surrounding clouds, resulting in more of the larger particles activating. The cloud droplet number could remain constant despite the lower supersaturation in the track because of the increased concentration of accumulation-mode particles in the track relative to the surrounding clouds.

Another possibility is that the increase in residual particle mass (as reflected in an increase in mean size of the residual particles) could have been due to cocondensation of other volatile compounds, which could subsequently be transformed to nonvolatile mass (Kulmala et al. 1996).

\section{2) TRAnsect 11}

Figure 7 shows the time series for transect 11 . The track at this encounter had become about $10 \mathrm{~km}$ wide. 

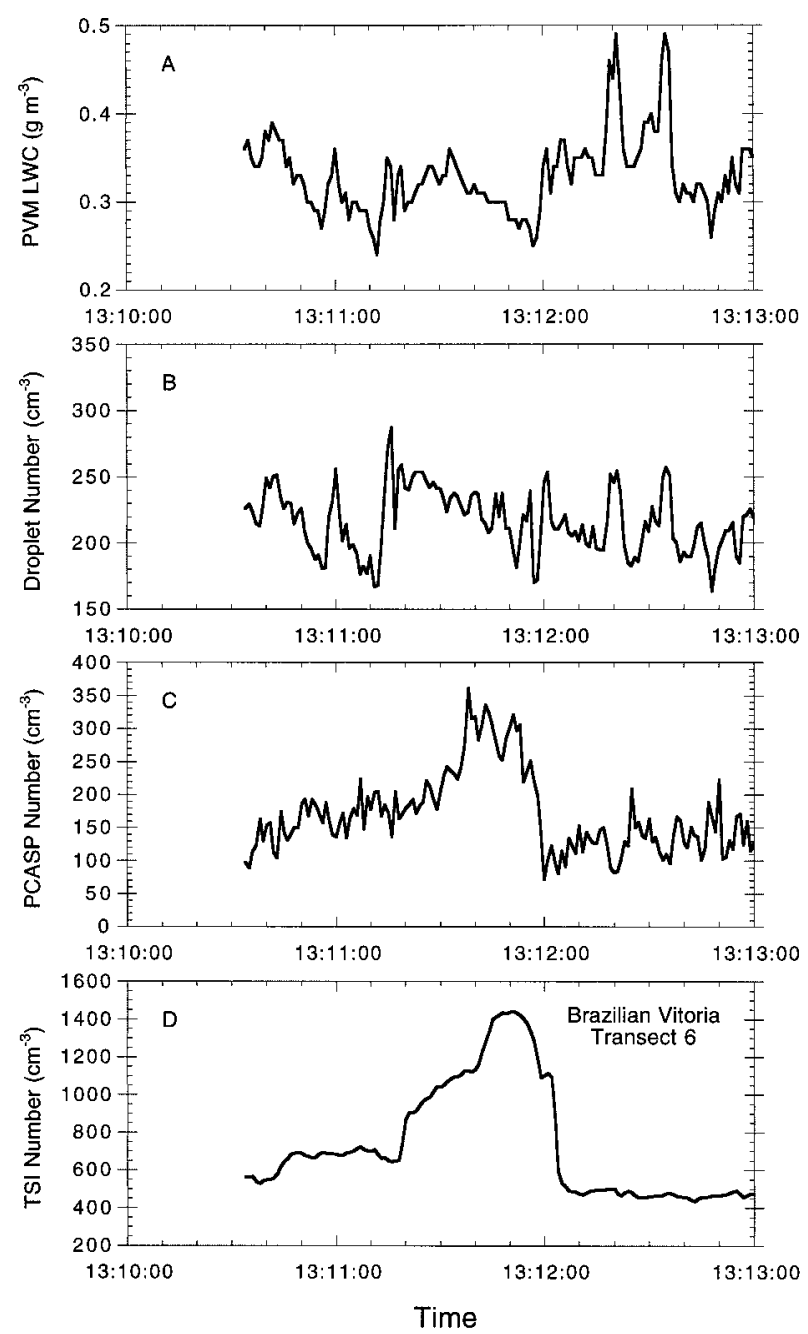

FIG. 5. Time series for transect 6, $8.5 \mathrm{~km}$ the Brazilian Vitoria. Track age was approximately $3 \mathrm{~h}$. Measurements were made aboard the UW C-131A. (a) Liquid water content from PVM-100A; (b) droplet number concentration from PMS FSSP-100X; (c) accumulationmode aerosol number concentration from PCASP 100-X; (d) aerosol number concentration from TSI 3760 condensation particle counter.

Figure $7 \mathrm{~d}$ shows the total particle concentration during the transect. Total particle number increased by $37 \%$ inside the track relative to the surrounding clouds, and accumulation-mode particle concentration increased by $30 \%$. The bars just above the plot in Fig. $7 \mathrm{~d}$ show the periods over which the before-track, track, and aftertrack averages were calculated. The accumulation-mode particle concentration did not increase as much in this transect as in the previous one. No track signature is apparent in either droplet number (Fig. 7b) or liquid water content (Fig. 7a). Droplet effective radius varied between 8.8 and $8.3 \mu \mathrm{m}$ and was no different in the track than in the ambient clouds.

Drop size distributions for transect 11 are shown in Fig. 8a. The three curves are essentially identical. As in the other transects, no change in cloud microphysics
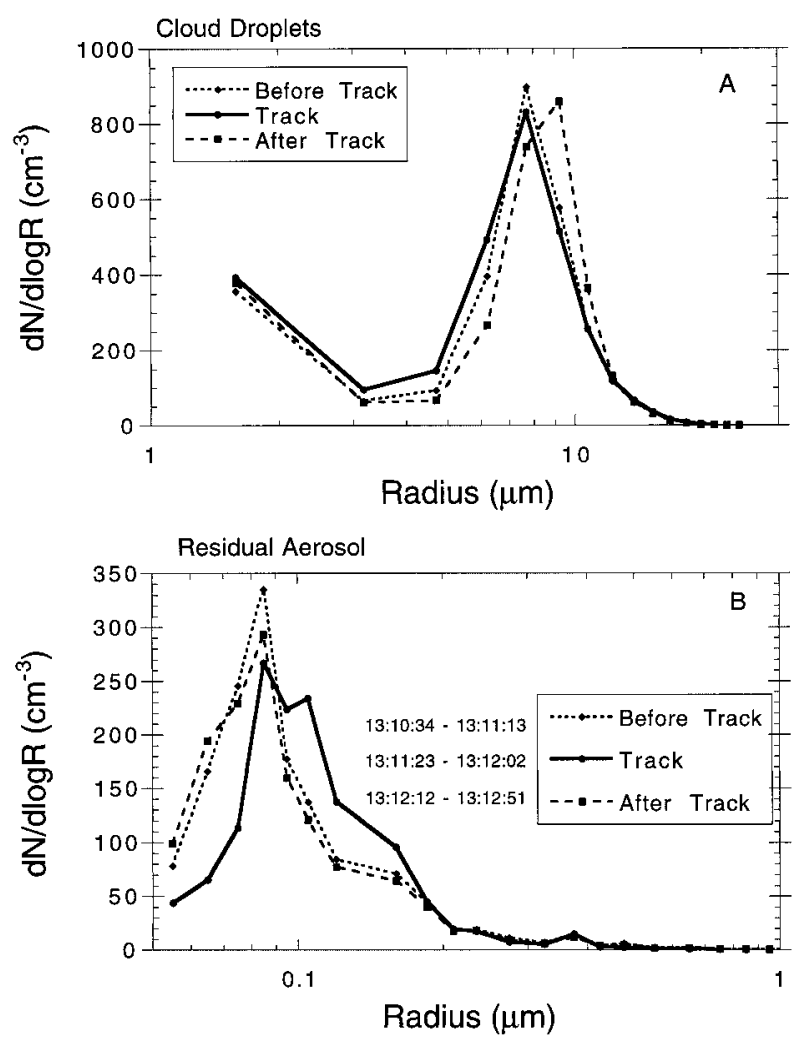

FIG. 6. Before-track, track, and after-track average size distributions for transect 6. (a) shows droplet size distributions from the PMS FSSP-100; (b) shows residual particle distributions taken using the PCASP-100 downstream of the CVI.

was apparent. Figure $8 \mathrm{~b}$ shows the residual particle size distributions for transect 11 . No change in residual particle size distribution was observed in this case. As with the droplets themselves, the droplet residual particles were no different in the track than in the surrounding clouds at this point.

Interstitial aerosol size distributions for this transect measured with the RCAD instrument on the UW C-131A are shown in Fig. 9. A modified version of the MICRON algorithm (Wolfenbarger and Seinfeld 1990; Russell et al. 1995, 1996) was used to invert the size distribution measurements from the RCAD.

The interstitial size distributions for the ambient clouds and ship track were similar; both showed modes at between 0.03 and $0.04 \mu \mathrm{m}$ and at $0.08-\mu \mathrm{m}$ radius. There was a small additional peak in particle number at $0.01-\mu \mathrm{m}$ radius in the ship track sample, and there were more particles in the ship track sample than in the ambient cloud interstitial aerosol. Most of the additional particles in the ship track at this location were primarily in the size range between the two upper modes of the distribution.

\section{3) Particle chemistry and microphysics}

Single particle analysis was carried out on samples of cloud droplet residual particles in ambient clouds as 

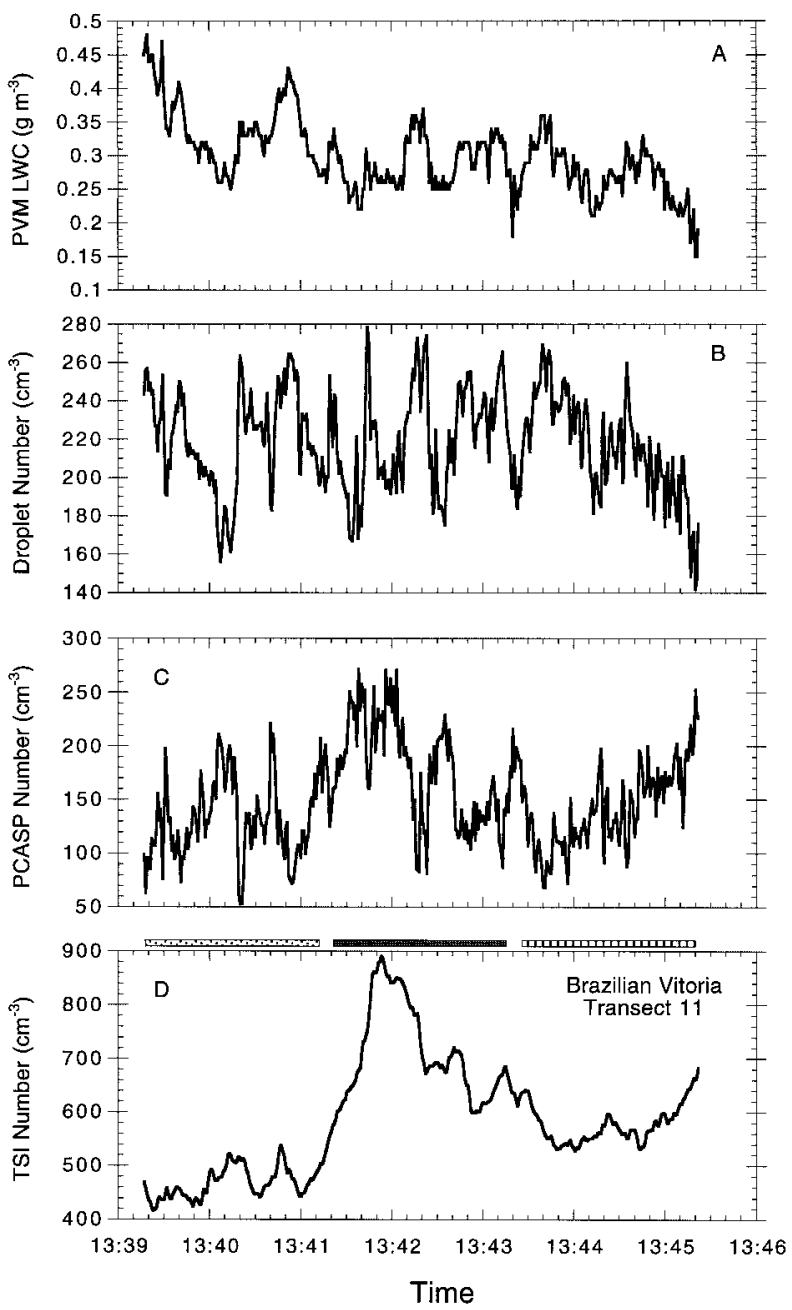

FIG. 7. Time series for transect 11 of the Brazilian Vitoria track, $16 \mathrm{~km}$ from the ship. Track age was approximately $6 \mathrm{~h}$. Measurements and instruments are the same as in Fig. 5.

well as on samples of Brazilian Vitoria ship track residual particles. Particle samples were placed in a scanning electron microscope (JEOL JSM-6300) and the size, morphology, and chemical composition of the particles were determined using electron probe X-ray microanalysis techniques (Xhoffer et al. 1992). The lower size limit for single particle analysis was $0.1-\mu \mathrm{m}$ radius; particles below this size were not resolved. A total of 500 particles per sample were analyzed. Once particle size and composition were determined, a hierarchical cluster analysis was performed that grouped individual particles with similar compositions (Bondarenko et al. 1996).

Figure 10 shows results for the filter samples of ambient cloud droplet residual particles (Fig. 10a) and Brazilian Vitoria ship track droplet residuals (Fig. 10b). The ambient cloud droplet residuals (larger than $0.1-\mu \mathrm{m}$ radius) were by number mostly a combination of sea salt and sulfate. The two most abundant clusters $(44.6 \%$ and
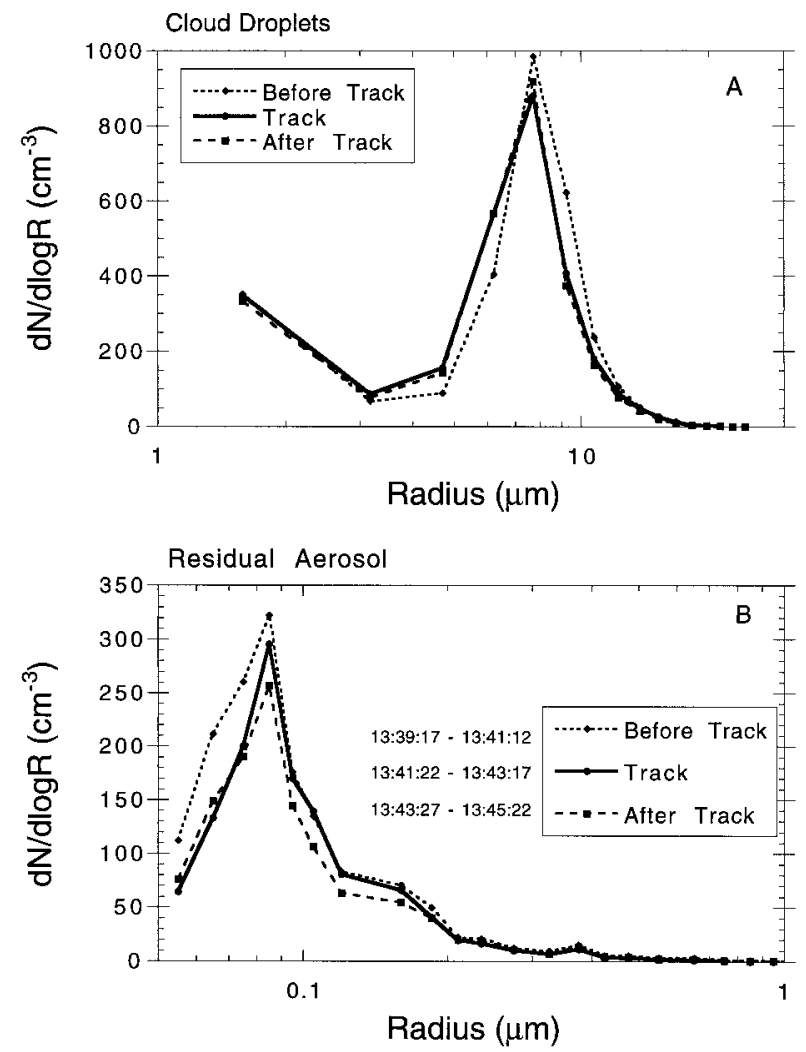

FIG. 8. Before-track, track and after-track average size distributions for transect 11. (a) shows droplet size distributions; (b) shows residual particle distributions. Instruments and measurements are the same as in Fig. 6.

$25.8 \%$ by number, respectively) contained $\mathrm{Cl}, \mathrm{S}$, and $\mathrm{Na}$, indicating an aged aerosol. These differed in the ratio of the peak intensities among the elements, thus giving rise to two separate clusters of the same elemental composition. These two clusters containing the same elements in different proportions may represent particles of different ages or different degrees of transformation. The third cluster, which accounted for $19.6 \%$ of the particles, was sea salt. The fourth cluster $(10 \%$ of the particles by number) also contained trace levels of magnesium, perhaps from a continental pollution source.

Similar elemental compositions were found for the first three ship track residual particle clusters. There was a larger fraction of particles in the sea salt $(\mathrm{Na}, \mathrm{Cl})$ cluster in the track sample (36.8\%) compared with the ambient sample (19.6\%). However, a second ambient residual sample collected in the same area resulted in a sea salt cluster that accounted for $31.6 \%$ of the particles. The difference between the ambient cloud and Brazilian Vitoria track samples in terms of sea salt was the same as the variation between two ambient cloud residual samples, so the ship did not appear to have been generating significant numbers of sea salt particles. The fourth cluster in the track sample contained $\mathrm{S}$ and organic material. This particular combination was only 


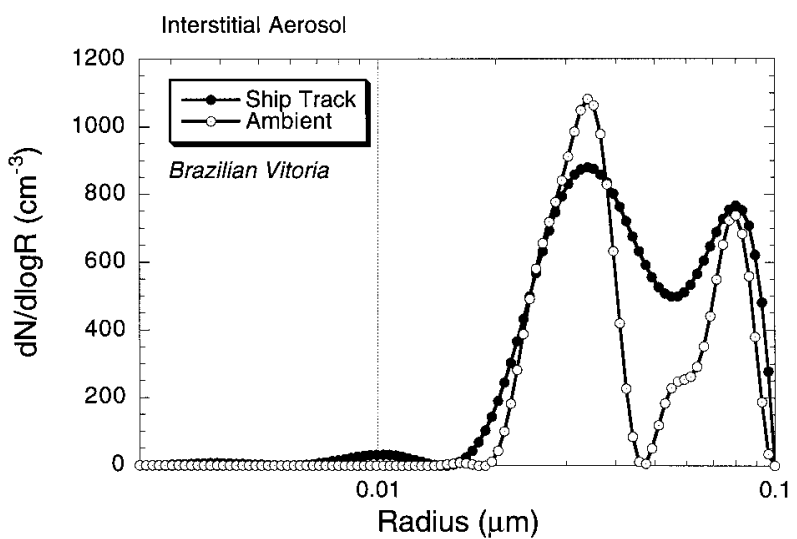

FIG. 9. Example interstitial aerosol size distributions for transect 11 of the Brazilian Vitoria track. Measurements made with the CIT RCAD instrument on the UW C-131A.

found in the Brazilian Vitoria ship track residual particles, and in neither of the ambient cloud residual particle samples on this flight. Russell et al. (2000) found combustion-derived organic compounds in cloud droplet residual particles during MAST. While a likely source of the particles giving rise to this cluster is combustion of diesel fuel by the ship, we cannot directly link these particles to the ship, since we do not have a corresponding below-cloud plume sample for the Brazilian Vitoria.

Filter samples of aerosol particles were obtained on the UW C-131A for analysis of bulk ionic composition. Two inlets were used; one sampled the total aerosol while the other sampled particles smaller than $1.75-\mu \mathrm{m}$ radius. Samples were obtained in the Brazilian Vitoria plume and in the ambient air below cloud. Figure 10c shows the results for four filter samples taken on this flight. Very little difference was observed in total aerosol concentrations and compositions between the plume and ambient samples. Both concentrations were close to $1.2 \mu \mathrm{g} \mathrm{m}^{-3}$ and had similar compositions. The ambient $<1.75-\mu \mathrm{m}$ radius sample concentration was a factor of 3 lower than the total aerosol sample, whereas the plume sub-1.75- $\mu \mathrm{m}$ diameter sample concentration was circa $80 \%$ of the total aerosol sample.

The MRF C-130 flew through the Brazilian Vitoria plume below cloud at two distances from the ship. Figure 11 shows aerosol size distributions measured at $40^{\circ} \mathrm{C}$ in a below-cloud penetration and an in-cloud (interstitial) run at $12 \mathrm{~km}$ from the ship. The background aerosol distribution shows a mode at $0.1-\mu \mathrm{m}$ radius. The plume size distribution is nearly identical to the background distribution above $0.08 \mu \mathrm{m}$ and shows a large increase in particle number below this size. The smaller mode in the plume size distribution was not resolved. The Brazilian Vitoria was thus producing significant numbers of particles of sizes below $0.08 \mu \mathrm{m}$, and not larger ones. The interstitial size distributions for the in-cloud pass show that few of the ship-produced particles below
$0.07 \mu \mathrm{m}$ were being scavenged into the cloud droplets at this location.

Converting the number size distributions for the background aerosol and Brazilian Vitoria plume measured with the UMIST aerosol thermal volatility system (VACC) on the MRF C-130 to mass distributions (assuming a particle density of $1.77 \mathrm{~g} \mathrm{~cm}^{-3}$ —ammonium sulfate) can be used as a comparison with the filter samples obtained from the UW C-131A. The integrated VACC mass size distributions give 3.1 and $3.6 \mu \mathrm{g} \mathrm{m}^{-3}$ for the background aerosol and plume concentrations, respectively. These figures can be compared with the values of 0.4 and $1.3 \mu \mathrm{g} \mathrm{m}^{-3}$ from the filter samples of the major ionic species. Both techniques are consistent in showing that the sub-1.75- $\mu \mathrm{m}$ diameter fraction of mass in the Brazilian Vitoria plume was higher than for the ambient aerosol. However, the $0.4 \mu \mathrm{g} \mathrm{m}^{-3}$ concentration observed in the $<1.75-\mu \mathrm{m}$ ambient filter sample from the UW C-131 may have been artificially low due to problems recording start and stop times for the filter.

Another pass through the plume below cloud was flown by the MRF C-130 at $40 \mathrm{~km}$ from the ship. Figure 12 shows time series of accumulation-mode aerosol particles for this run at $40^{\circ}$ and $340^{\circ} \mathrm{C}$ using the UMIST VACC system, as well as accumulation-mode concentrations measured by a wing-mounted passive cavity aerosol spectrometer probe (PCASP). The ship's plume is clearly evident in the PCASP time series just after 1442 local time. Accumulation-mode number concentration at $40^{\circ} \mathrm{C}$ measured independently with the VACC system agrees well with the PCASP concentrations both before and after the plume. Just before the plume encounter, the VACC system was adjusted to sample at $340^{\circ} \mathrm{C}$ to see whether the plume was due to the sea salt particles being generated by the ship. No corresponding peak was seen in the time series for $340^{\circ} \mathrm{C}$, which shows that the particles being emitted from the ship were not sea salt in nature. Thus, three independent measurements of sea salt particles on two different aircraft are consistent in indicating that sea salt particles generated by the ship did not cause the observed ship track in this case.

\section{b. Kurama}

A series of runs perpendicular to the Kurama track were flown by the MRF C-130 at approximately 30 and $85 \mathrm{~km}$ down the plume from the ship. These were followed by a long run back toward the ship below cloud during which the $\mathrm{C}-130$ zigzagged across the plume attempting to map its position and study its evolution.

\section{1) Cloud AND Aerosol PROperties}

During the first of the series of horizontal transects of the plume, runs were made at an altitude of $150 \mathrm{~m}$ (below cloud), $440 \mathrm{~m}$ (near cloud tops), and at $762 \mathrm{~m}$ (above cloud). As seen in Figs. 13a,b, during the runs 

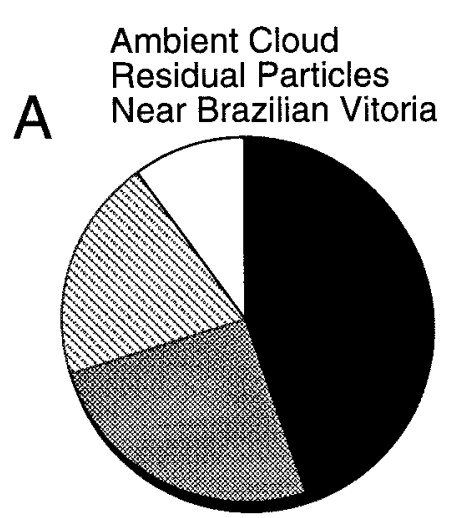

$\mathrm{Cl}, \mathrm{S}, \mathrm{Na}(44.6 \%)$

Q $\mathrm{Cl}, \mathrm{S}, \mathrm{Na}(25.8 \%)$

D Cl, $\mathrm{Na}(19.6 \%)$

$\square \mathrm{Cl}, \mathrm{S}, \mathrm{Na}, \mathrm{Mg}(10.0 \%)$

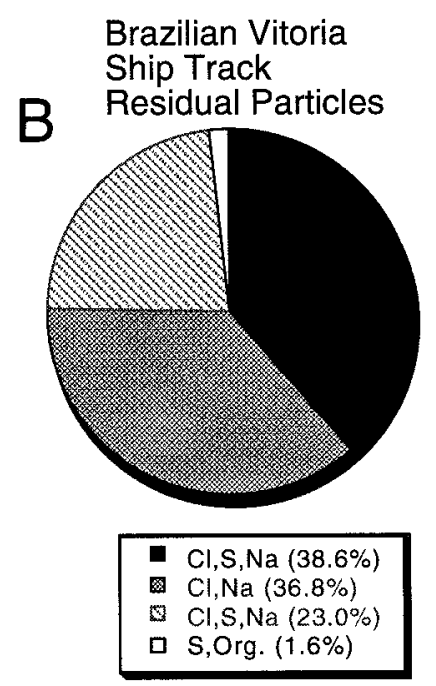

园 $\mathrm{Cl}, \mathrm{Na}(36.8 \%)$

$\mathrm{Cl}, \mathrm{S}, \mathrm{Na}\left(23.0^{\circ}\right)$

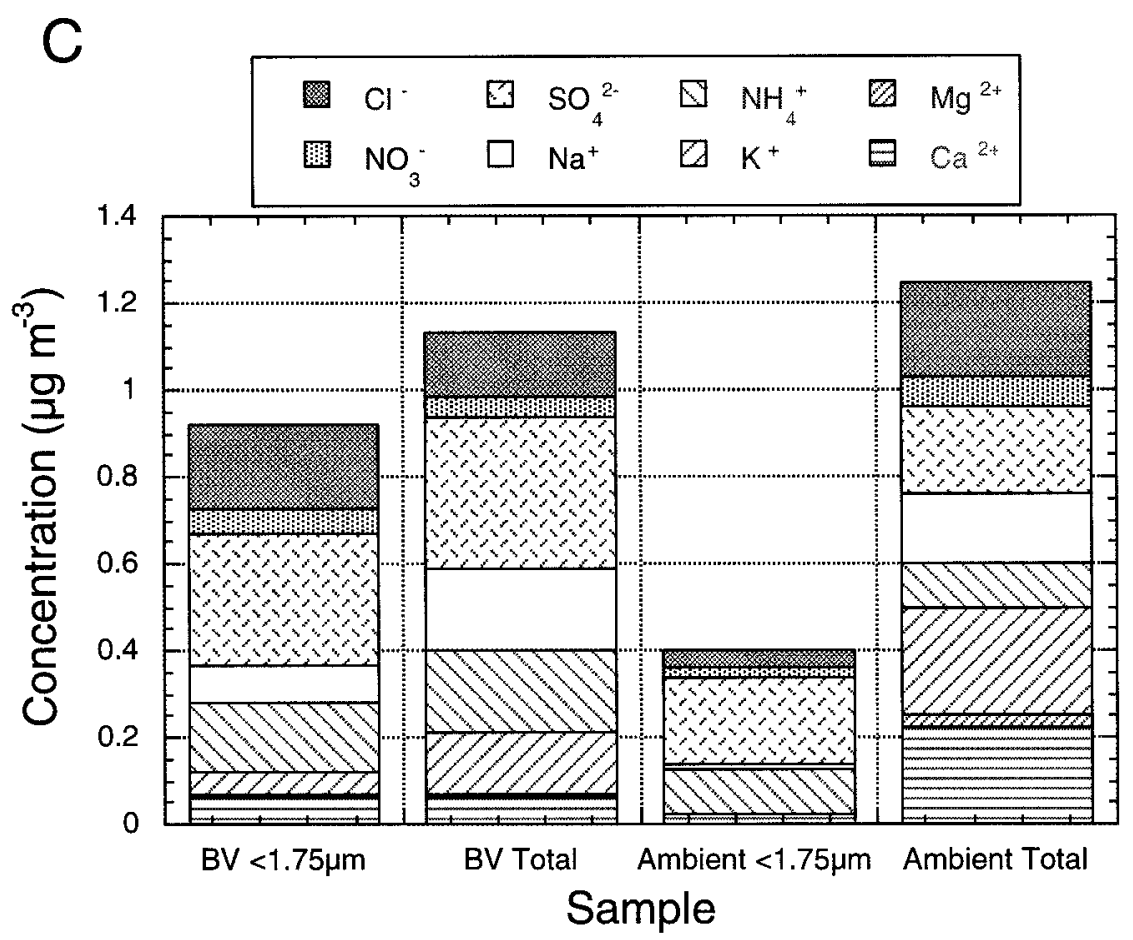

FIG. 10. Results of a hierarchical cluster analysis of the elemental composition of cloud droplet residual particles. (a) is for ambient cloud drop residuals; (b) is for residuals from the Brazilian Vitoria ship track. 500 particles per filter sample were analyzed. Filters were collected using the CVI. (c) shows bulk chemical analysis results of aerosol filters. "BV" denotes Brazilian Vitoria plume sample, "ambient" an ambient aerosol sample. The "total" sample is from an isokinetic inlet, the " $<1.75 \mu \mathrm{m}$ " from an inlet with an upper cut size of $1.75-\mu \mathrm{m}$ radius. All samples were collected from the UW C-131A.

below cloud a peak in the aerosol accumulation mode concentration of $700 \mathrm{~cm}^{-3}$ was observed; this was significantly higher than the mean concentration along the run (outside the plume) of $270 \mathrm{~cm}^{-3}$. The mean radius of the accumulation mode aerosol was observed to de- crease in the plume to $0.09 \mu \mathrm{m}$; the mean radius over the entire run was $0.124 \mu \mathrm{m}$.

The run in cloud at this distance from the ship (Figs. $13 \mathrm{c}, \mathrm{d}, \mathrm{e})$ showed a significant increase in interstitial aerosol in the position in the ship track, which was 


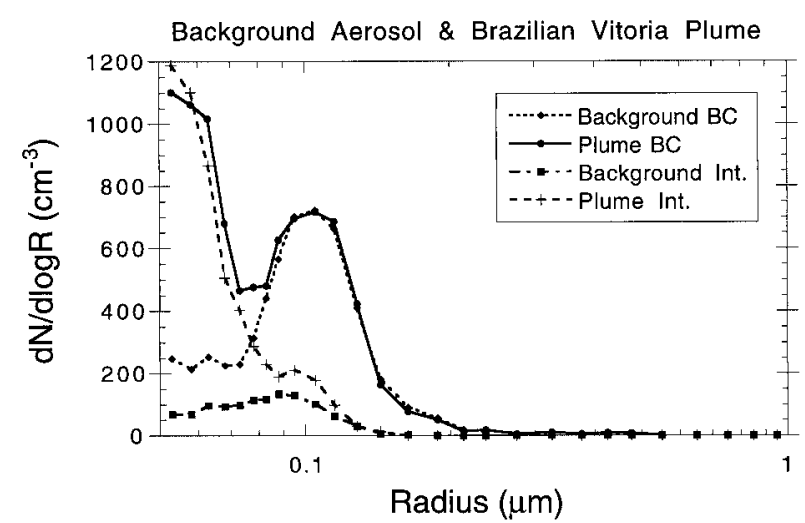

FIG. 11. Comparison of aerosol size distributions (below cloud and interstitial) measured at $40^{\circ} \mathrm{C}$ for the background and Brazilian Vitoria plume. Measurements made with the UMIST VACC system on the MRF C-130.

correlated with a small increase in cloud droplet concentration from around 250 to $290 \mathrm{~cm}^{-3}$. Conditional sampling in the region of this increase in droplet concentration indicates that the effective radius, as measured by the FSSP, was reduced from an average of 7.4 $\mu \mathrm{m}$ outside the plume to $7.1 \mu \mathrm{m}$ within the plume. However, the standard deviation of the effective radius along the entire run was $0.33 \mu \mathrm{m}$; that is, the impact of the plume on the cloud microphysics at this distance from the ship was not significant.

\section{2) RADIATIVE PROPERTIES}

A run was then flown $260 \mathrm{~m}$ above cloud top during which the Multi-Channel Radiometer (MCR) made measurements of the nadir reflectance at wavelengths of 1.25 and $2.26 \mu \mathrm{m}$. Using these measurements of reflectance, one at a strong absorbing wavelength for liquid water and another at a weak absorbing wavelength, it is possible to retrieve both the cloud optical depth and the effective radius of the cloud top (Taylor 1992). Figure 14 (upper panel) shows the in situ effective radius measured by the FSSP and that computed from the combined FSSP and 2DC spectra, both measured during the run near cloud top.

Superimposed on the same figure is the MCR retrieved effective radius from the subsequent run above cloud. As can be seen there is no evidence of a cloud microphysical signature associated with the increased aerosol concentrations below cloud, in either the FSSP, FSSP plus 2DC, or the MCR retrieved effective radius. The accuracy of the MCR retrieval of effective radius is estimated to be around $1.5 \mu \mathrm{m}$ (Taylor 1992). The lower panel of Fig. 14 shows the MCR retrieved optical depth at a wavelength of $1.25 \mu \mathrm{m}$. The optical depth is quite variable ranging from 11 to 23 and shows no clear indication of any radiative impact of the increased aerosol concentrations on the cloud layer.

Using measurements of the liquid water content, ef-

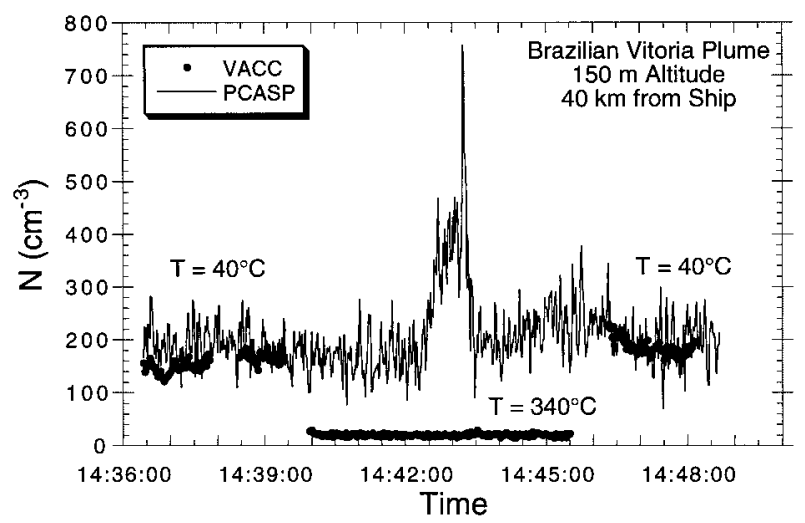

FIG. 12. Time series of aerosol at (near) ambient temperature, $40^{\circ}$ and $340^{\circ} \mathrm{C}$, for a below-cloud transect of the Brazilian Vitoria plume. Measurements made with the UMIST VACC system on the MRF C-130.

fective radius, and droplet concentration within cloud and the visible albedo above cloud it is possible to compute the cloud susceptibility (Taylor and McHaffie 1994), defined as (under the condition of conserved liquid water)

$$
\frac{d A}{d N}=\frac{4 \pi \rho_{l}}{9 L} A(1-A) k r_{e}^{3},
$$

where $A$ is albedo, $N$ is drop concentration, $k$ is a constant that has the value $k=0.8$ in maritime air masses or $k=0.67$ in continental air masses, $\rho_{1}$ is the liquid water density, $L$ is the liquid water content of the cloud, and $r_{e}$ the effective radius of the droplet distribution. In these calculations the type of air mass and hence the value of $k$ has been determined from the aerosol concentration using the criteria of Martin et al. (1994).

The susceptibility of the cloud measured during this flight, outside of the influence of the ship, was found to be $0.47 \times 10^{-3} \mathrm{~cm}^{3}$. A susceptibility of $0.01 \mathrm{~cm}^{3}$ means that the increase in droplet density by $1 \mathrm{~cm}^{-3}$ would increase albedo by 0.01 . If one takes this background susceptibility and then increments the droplet concentration from the background value to that in the plume in discrete steps, at each interval recomputing the effective radius and susceptibility, one finds that the predicted change in cloud droplet effective radius is a decrease of around $0.2 \mu \mathrm{m}$ and the albedo over the plume would be expected to increase by 0.017 . These changes are small and show why it is difficult to observe a clear radiative or microphysical signature of the $\mathrm{Ku}$ rama and Brazilian Vitoria plumes in the cloud. It should be noted that such a simple calculation requires the conservation of liquid water content as the droplet concentration increases. Further, it does not allow for any other changes in the basic cloud structure that may occur as a result of changing the cloud microphysics. It is, however, useful as an illustration of the relative insensitivity of this continentally modified cloud field to localized changes in aerosol concentration and of how 

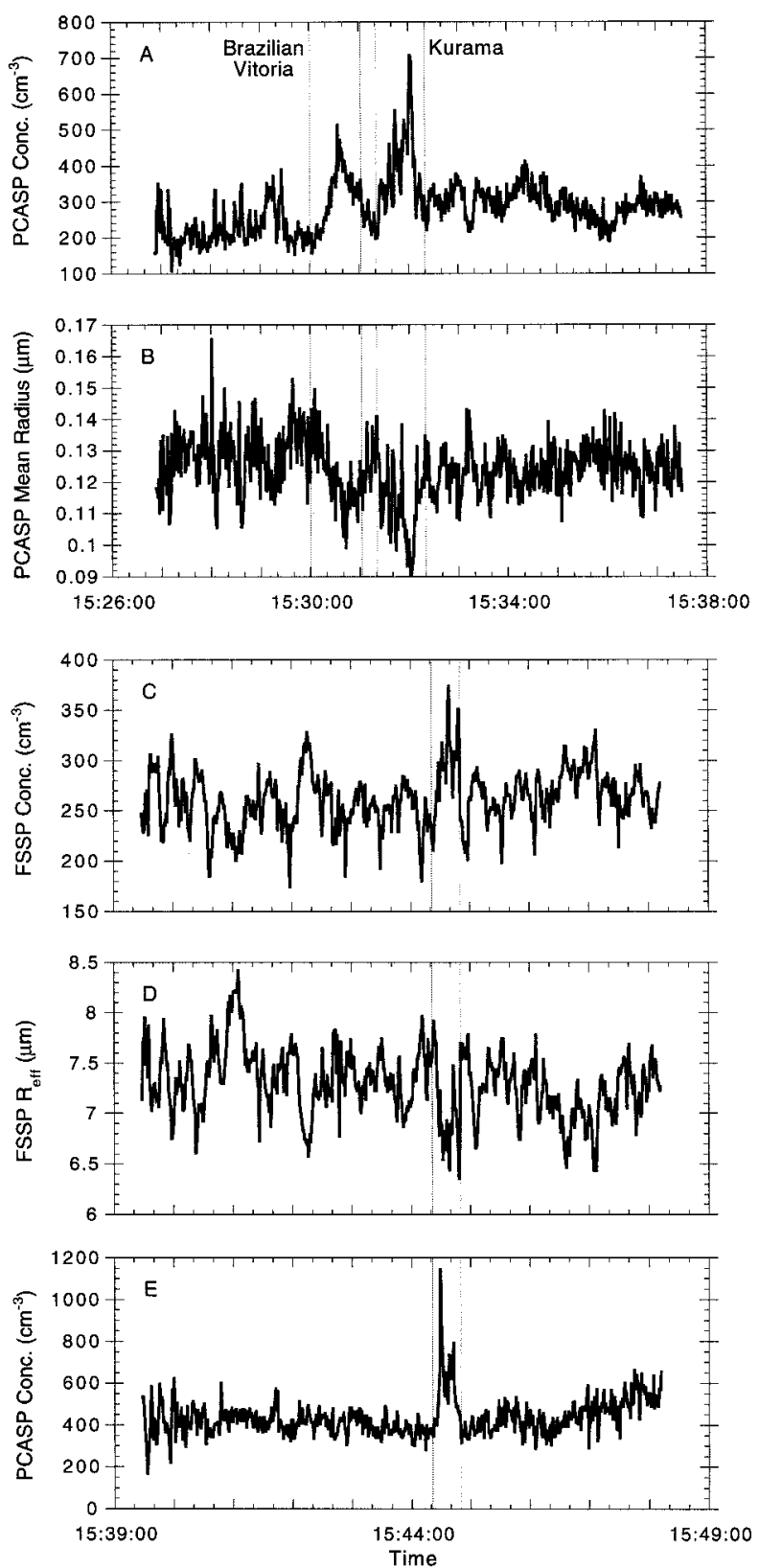

FIG. 13. Time series for two crossings of the Kurama ship track. (a) and (b) are for a transect near the point at which the two tracks crossed. (c)-(e) are for a second transect of the Kurama track. The shaded areas indicate plume encounters. Instruments: PCASP-100 (a), (b), and (e); FSSP-100 (c) and (d). Measurements made from the MRF C-130.

important the microphysical characteristics of the background cloud field are in determining whether a ship track will be detectable.

A series of runs at approximately $85 \mathrm{~km}$ down the plume from the ship were also carried out, and these show some evidence of a radiative and microphysical signature in the cloud associated with the Kurama plume observed below the cloud. Figure 15 shows the accu-
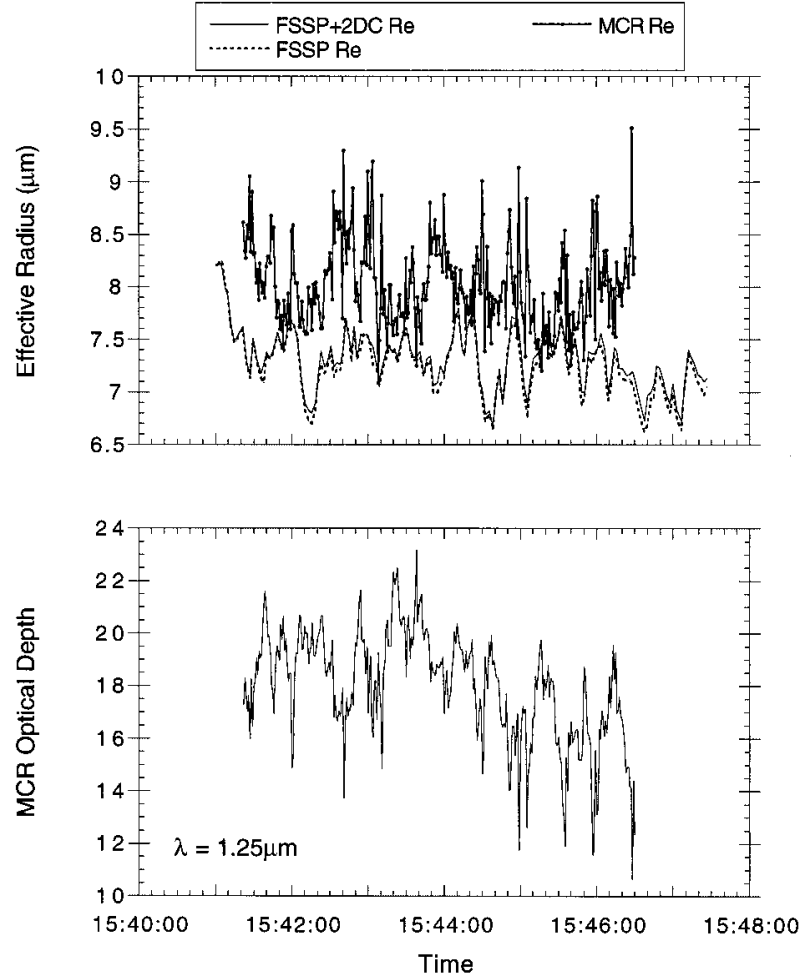

FIG. 14. Time series of droplet effective radius (upper panel) derived from the FSSP alone, FSSP and 2DC probes, and retrieved from reflectance measurements made with the MCR during a subsequent run above cloud. The lower panel shows the optical depth retrieved during the run above cloud. Measurements from the MRF C-130.

mulation-mode aerosol concentration as measured during a run below cloud along with the optical depth of the cloud layer retrieved at a wavelength of $0.55 \mu \mathrm{m}$ with the MCR viewing in the zenith.

It should be noted that the retrieved optical depths, here measured in transmission, are in broad agreement with those measured in reflection in Fig. 14. At around 1619 local time there was a marked increase in the aerosol concentration below cloud where the presence of the ship exhaust led to almost a doubling in the accumulation-mode concentration. The optical depth retrieval shows a gradual increase in optical depth along the run with a marked increase from around 17 to 25 in the same region as the increase in aerosol was observed. The increase in optical depth along the run is attributed to a gradual thickening of the cloud toward the east, which was observed throughout the flight. The increase in optical depth in the region of the ship plume is too large to be considered as due to an increase in the aerosol optical depth; rather, it is associated with an increase in the cloud liquid water path or a decrease in cloud droplet effective radius.

\section{3) Kurama Plume/Background AEROSOL COMPARISON}

Thermal volatility data were also obtained for the Kurama plume below cloud. Figure 16 shows Kurama 


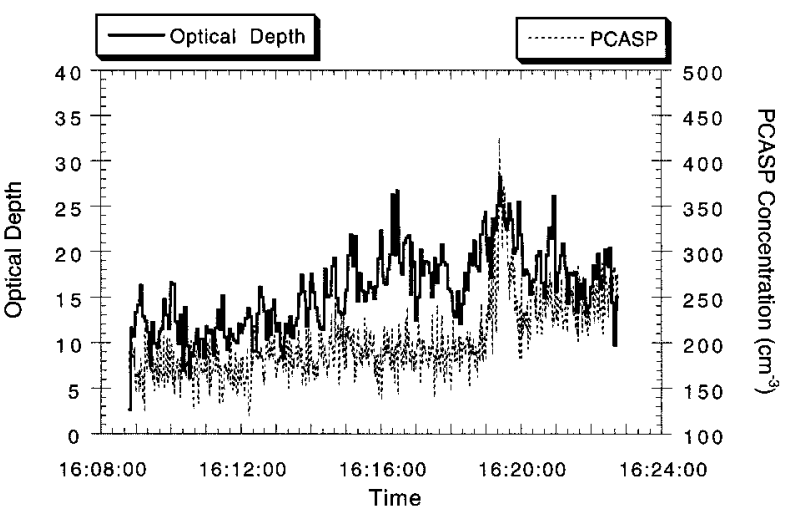

FIG. 15. Cloud optical depth and accumulation-mode concentration time series across the Kurama track. Instruments: PCASP-100; optical depth derived from MCR nadir reflectance measurements at 1.25 and $2.26 \mu \mathrm{m}$. Measurements from the MRF C-130.

plume and background aerosol size distributions at three temperatures. In contrast to the Brazilian Vitoria plume, the distributions at $40^{\circ} \mathrm{C}$ (Fig. 16a) show that the $\mathrm{Ku}$ rama produced additional particles relative to background concentrations up to about $0.2-\mu \mathrm{m}$ radius. The major difference again, however, was for particles below $0.07 \mu \mathrm{m}$. Upon heating to $150^{\circ} \mathrm{C}$, the differences between the plume and background aerosol became much smaller; the small difference that was observed was confined to particles below $0.09-\mu \mathrm{m}$ radius. The change between $40^{\circ}$ and $150^{\circ} \mathrm{C}$ suggests that the Kurama was producing primarily particles volatile between these two temperatures. The plume and background aerosol distributions at $340^{\circ} \mathrm{C}$ are identical, indicating that accumulation-mode sea salt particles were not being produced by the Kurama.

\section{c. Comparison of track characteristics}

Both the Brazilian Vitoria and the Kurama ship tracks were clearly seen in the 3.7- $\mu \mathrm{m}$ AVHRR imagery from 11 June. They appear as an " $X$ " in the lower part of Fig. 2. However, neither track appeared in the visible $(0.63 \mu \mathrm{m})$ AVHRR imagery, nor in the high-resolution MAS imagery at $0.657 \mu \mathrm{m}$. In situ measurements of cloud microphysical properties show that the droplet size distributions and effective radii did not change substantially in the tracks above the background variability. A difference in radiative properties of ship tracks and ambient clouds derived from in situ measurements was observed only in a single case (shown in Fig. 15).

Platnick et al. (2000) discuss the differences between the response of the AVHRR instrument at the two wavelengths in question in terms of the relative change in bidirectional reflectance as seen from satellite or airborne platforms. They point out that the reflectance for a particular wavelength band is a function of the cloud optical depth $(\tau)$ and droplet effective radius $\left(r_{e}\right)$. They define the relative susceptibility as $(1 / R)(d R / d N)$ where
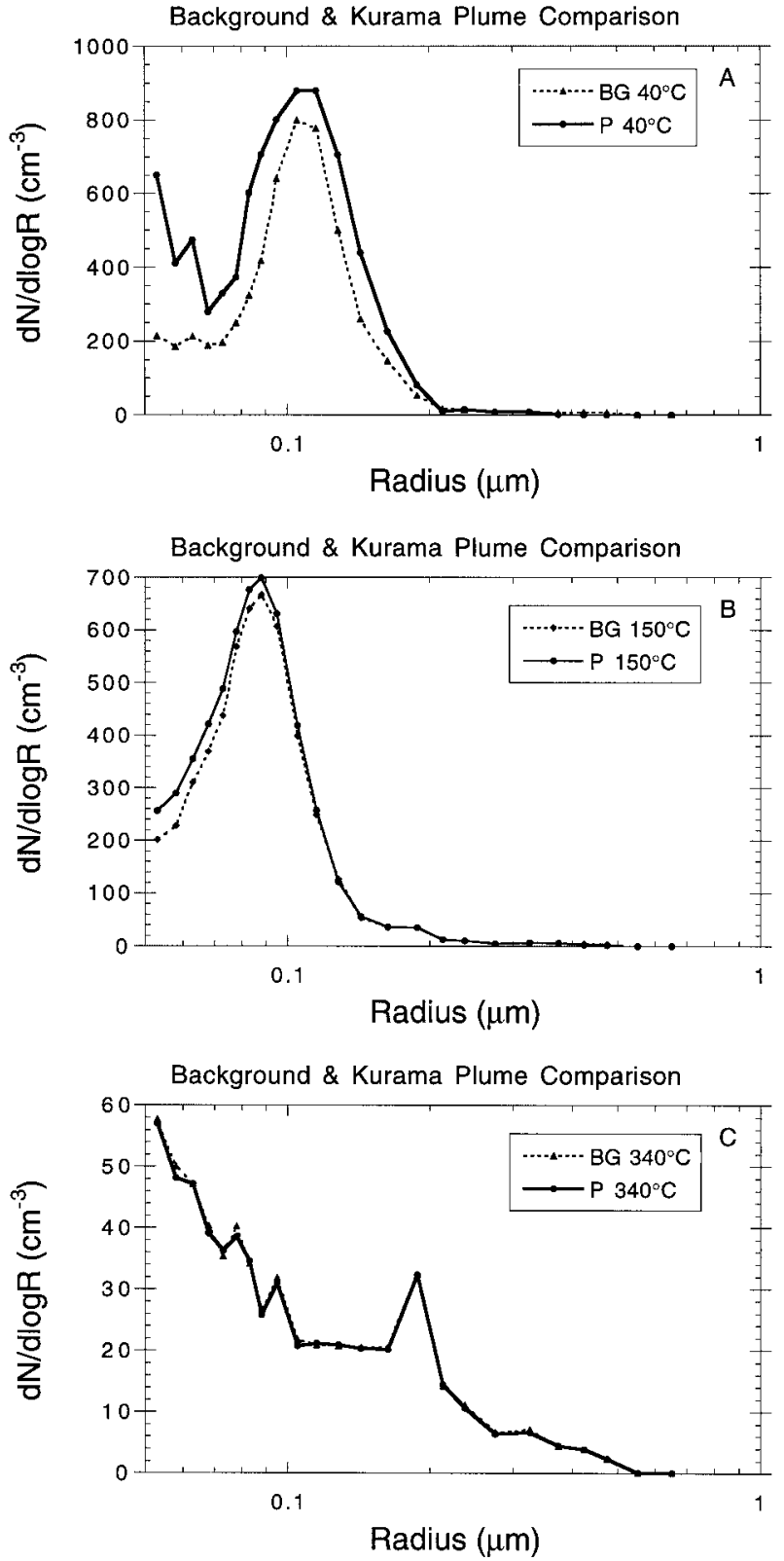

FIG. 16. Comparison of aerosol size distributions for the Kurama plume and background aerosol for (a) $40^{\circ}$, (b) $150^{\circ}$, and (c) $340^{\circ} \mathrm{C}$. Measurements made with the UMIST VACC system on the MRF C-130.

$R\left(\tau, r_{e}\right)$ is the bidirectional reflectance and $N$ is the droplet number concentration. They show that for a wide range of optical depths and effective radii, the relative susceptibility of the $3.7-\mu \mathrm{m}$ channel is between a factor of 2 and 8 larger than the visible channel. We can therefore expect ship tracks to more readily appear in the 3.7- $\mu \mathrm{m}$ images than in the visible ones.

Both ships were producing accumulation-mode aerosol particles. Ship emissions are discussed in detail in another paper (Hobbs et al. 2000). For the discussion 
presented here, the primary differences in aerosol size distributions between the ship plume and background aerosol were for dry particle sizes smaller than about $0.07-\mu \mathrm{m}$ radius. Neither ship appeared to have been generating a substantial amount of sea salt particles above background levels.

\section{Conclusions}

Two ship tracks were observed in 3.7- $\mu \mathrm{m}$ AVHRR imagery, and in situ measurements of cloud microphysics and aerosol microphysics and chemistry were made in both tracks. Neither of the tracks was apparent in any of the visible wavelength imagery. The observed changes in droplet size distributions, effective radius, number concentration, and liquid water content between the ship tracks and ambient clouds were (with the exception of a single case) within the variability of the background clouds themselves.

Concerning the radiative properties of the clouds, we can conclude that the lack of any significant changes in cloud microphysics resulted in the tracks not appearing in the visible imagery. The fact that they were seen in the infrared imagery was probably because the $3.7-\mu \mathrm{m}$ relative contrast is always greater than for visible wavelengths.

The ships were not producing a significant amount of sea salt aerosol; the additional particles found in the ship plumes must have originated from stack emissions.

Ship tracks do form in polluted marine boundary layers. They are most apparent in the near-infrared where the relative susceptibility is highest. We see that anthropogenic emissions of aerosols can have an influence on the radiative properties of even polluted clouds, at least in the near-infrared.

Acknowledgments. We are indebted to the pilots, captain, and crews of the UW C-131A, the MRF C-130, the NRL airship, and the R/V Glorita for their excellent work during the field campaign. Drs. Wendell Nuss and Chuck Wash at NPS provided valuable forecasting and meteorological analysis during the campaign. This project was funded by the Office of Naval Research. The support provided by Bob Bluth from ONR was indispensable, and the project would not have been a success without his efforts.

\section{REFERENCES}

Bondarenko, I., R. Treiger, and R. E. Van Grieken, 1996: IDAS, a Windows based software package for cluster analysis. Spectrochim. Acta, 51B, 441-456.

Brown, P. R. A., 1993: Measurements of the ice water content in cirrus using an evaporative technique. J. Atmos. Oceanic Technol., 10, 579-590.

Clarke, A. D., N. C. Ahlquist, and D. S. Covert, 1987: The Pacific marine aerosol: Evidence for natural acid sulfates. J. Geophys. Res., 92D, 4179-4190.

Coakley, J. A., Jr., R. L. Bernstein, and P. A. Durkee, 1987: Effect of ship-stack effluents on cloud reflectivity. Science, 237, 1020-1022.
Conover, J. H., 1966: Anomalous cloud lines. J. Atmos. Sci., 23, 778785.

Durkee, P. A., and Coauthors, 2000a: Composite ship track characteristics. J. Atmos. Sci., 57, 2542-2553.

- K. J. Noone, and R. T. Bluth, 2000b: The Monterey Area Ship Track experiment. J. Atmos. Sci., 57, 2523-2541.

— on the microstructure and albedo of warm marine stratocumulus clouds: A test of MAST hypotheses 1i and 1ii. J. Atmos. Sci., 57, 2554-2569.

Ferek, R. J., and Coauthors, 2000: Drizzle suppression in ship tracks. J. Atmos. Sci., 57, 2707-2728.

Hobbs, P. V., L. F. Radke, J. H. Lyons, R. J. Ferek, D. J. Coffman, and T. J. Casadevall, 1991: Airborne measurements of particle and gas emissions from the 1990 volcanic eruptions of Mount Redoubt. J. Geophys. Res., 96, 18 735-18 752.

- and Coauthors, 2000: Emissions from ships with respect to their effects on clouds. J. Atmos. Sci., 57, 2570-2590.

Hudson, J. G., 1989: An instantaneous CCN spectrometer. J. Atmos. Oceanic Technol., 6, 1055-1065.

King, M. D., L. F. Radke, and P. V. Hobbs, 1993: Optical properties of marine stratocumulus clouds modified by ships. J. Geophys. Res., 98, 2729-2739.

Kulmala, M., P. Korhonen, T. Vesala, H.-C. Hansson, K. J. Noone, and B. Svenningsson, 1996: The effect of hygroscopicity on cloud droplet formation, Tellus, 48B, 347-360.

Martin, G. M., D. W. Johnson, and A. Spice, 1994: The measurement and parameterization of effective radius of droplets in warm stratocumulus clouds. J. Atmos. Sci., 51, 1823-1842.

Noone, K. J., J. A. Ogren, J. Heintzenberg, R. J. Charlson, and D. S. Covert, 1988: Design and calibration of a counterflow virtual impactor for sampling of atmospheric fog and cloud droplets. Aerosol Sci. Technol., 8, 235-244.

forming tracks in moderately polluted clouds. J. Atmos. Sci., 57, 2729-2747.

O'Dowd, C. D., and M. H. Smith, 1993: Physicochemical properties of aerosols over the northeast Atlantic: Evidence for wind speedrelated submicron sea-salt aerosol production. J. Geophys. Res., 98, 1137-1149.

Ogren, J. A., J. Heintzenberg, and R. J. Charlson, 1985: In-situ sampling of clouds with a droplet to aerosol converter. Geophys. Res. Lett., 12, 121-124.

Petersen, W. B., and L. G. Lavdas, 1986: Inpuff 2.0-A multiple source Gaussian puff dispersion algorithm. EPA/600/8-86/024, U.S. Environmental Protection Agency, Research Triangle Park, $\mathrm{NC}, 110 \mathrm{pp}$

Platnick, S., and S. Twomey, 1994: Determining the susceptibility of cloud albedo to changes in droplet concentration with the Advanced Very High Resolution Radiometer. J. Appl. Meteor., 33, 334-347.

— physics in the radiative formation of ship tracks. J. Atmos. Sci., 57, 2607-2624.

Radke, L. F., J. A. Coakley Jr., and M. D. King, 1989: Direct and remote sensing observations of the effects of ships on clouds. Science, 246, 1146-1149.

Rogers, D. P., D. W. Johnson, and C. A. Friehe, 1995: The stable internal boundary layer over a coastal sea. Part I: Airborne measurements of the mean and turbulence structure. J. Atmos. Sci., 52, 667-683.

Russell, L. M., R. C. Flagan, and J. H. Seinfeld, 1995: Asymmetric instrument response resulting from mixing effects in accelerated DMA-CPC measurements. Aerosol Sci. Technol., 23, 491-509.

— , S. H. Zhang, R. C. Flagan, and J. H. Seinfeld, 1996: Radially classified aerosol detector for aircraft-based submicron aerosol measurements. J. Atmos. Oceanic Technol., 13, 598-609.

- , K. J. Noone, R. J. Ferek, R. A. Pockalny, R. C. Flagan, and J. H. Seinfeld, 2000: Combustion organic aerosol as cloud 
condensation nuclei in ship tracks. J. Atmos. Sci., 57, 25912606.

Syrett, W. J., 1994: Low-level temperature and moisture structure from MAST: 5-29 June 1994. Pennsylvania State University Department of Meteorology Rep., 35 pp. [Available from Department of Meteorology, 503 Walker Building, The Pennsylvania State University, University Park, PA 16802.]

Taylor, J. P., 1992: Sensitivity of remotely sensed effective radius of cloud droplets to changes in LOWTRAN version. J. Atmos. Sci., 49, 2564-2569.

, and A. McHaffie, 1994: Measurements of cloud susceptibility. J. Atmos. Sci., 51, 1298-1306.
Twomey, S., 1974: Pollution and the planetary albedo. Atmos. Environ., 8, 1251-1256.

— 1991: Aerosols, clouds and radiation. Atmos. Environ., 25A, 2435-2442.

- H. B. Howell, and T. A. Wojciechowski, 1968: Comments on "Anomalous cloud lines." J. Atmos. Sci., 25, 333-334.

Wolfenbarger, J. K., and J. H. Seinfeld, 1990: Inversion of aerosol size distribution data. J. Aerosol Sci., 21, 227-247.

Xhoffer, C., L. Wouters, and R. E. Van Grieken, 1992: Characterization of individual particles in the North Sea surface microlayer and underlying seawater: Comparison with atmospheric particles. Environ. Sci. Technol., 26, 2151-2162. 